\title{
Expression of Quinone Reductase-2 in the Cortex Is a Muscarinic Acetylcholine Receptor-Dependent Memory Consolidation Constraint
}

\author{
Akiva N. Rappaport, ${ }^{1}$ Eyal Jacob, ${ }^{1}$ CVijendra Sharma, ${ }^{1}$ Sharon Inberg, ${ }^{1}$ Alina Elkobi, ${ }^{1}$ Hadile Ounallah-Saad, ${ }^{1}$ \\ Metsada Pasmanik-Chor, ${ }^{3}$ Efrat Edry, ${ }^{1,2}$ and Kobi Rosenblum ${ }^{1,2}$ \\ ${ }^{1}$ Sagol Department of Neurobiology and ${ }^{2}$ Center for Gene Manipulation in the Brain, University of Haifa, Haifa 3498838, Israel, and ${ }^{3}$ Bioinformatics Unit, \\ George Wise Faculty of Life Sciences, Tel-Aviv University, Tel-Aviv 6997801, Israel
}

Learning of novel information, including novel taste, requires activation of neuromodulatory transmission mediated, for example, by the muscarinic acetylcholine receptors ( $\mathrm{mAChRs)} \mathrm{in} \mathrm{relevant} \mathrm{brain} \mathrm{structures.} \mathrm{In} \mathrm{addition,} \mathrm{drugs} \mathrm{enhancing} \mathrm{the} \mathrm{function} \mathrm{of} \mathrm{mAChRs}$ are used to treat memory impairment and decline. However, the mechanisms underlying these effects are poorly understood. Here, using quantitative RT-PCR in Wistar Hola rats, we found quinone reductase 2 (QR2) to be expressed in the cortex in an mAChR-dependent manner. QR2 mRNA expression in the insular cortex is inversely correlated with mAChR activation both endogenously, after novel taste learning, and exogenously, after pharmacological manipulation of the muscarinic transmission. Moreover, reducing QR2 expression levels through lentiviral shRNA vectors or activity via inhibitors is sufficient to enhance long-term memories. We also show here that, in patients with Alzheimer's disease, QR2 is overexpressed in the cortex. It is suggested that QR2 expression in the cortex is a removable limiting factor of memory formation and thus serves as a new target to enhance cognitive function and delay the onset of neurodegenerative diseases.

Key words: cognitive function; cortex; learning; mAChR; memory consolidation; QR2 (NQO2)

\section{Significance Statement}

We found that: (1) quinone reductase $2(\mathrm{QR} 2)$ expression is a muscarinic-receptor-dependent removable constraint on memory formation in the cortex, (2) reducing QR2 expression or activity in the cortex enhances memory formation, and (3) Alzheimer's disease patients overexpressed QR2. We believe that these results propose a new mechanism by which muscarinic acetylcholine receptors affect cognition and suggest that inhibition of QR2 is a way to enhance cognition in normal and pathological conditions.

\section{Introduction}

Some sensory experiences do not form stable memories, whereas others form short-term memories, which last minutes to hours,

Received Jan. 27, 2015; revised Sept. 10, 2015; accepted 0ct. 5, 2015.

Author contributions: A.N.R., E.J., and K.R. designed research; A.N.R., E.J., V.S., S.I., A.E., H.O.-S., and E.E. performed research; A.N.R., E.J., V.S., S.I., A.E., H.O.-S., M.P.-C., and E.E. analyzed data; A.N.R. and K.R. wrote the paper.

This work was supported by European Union Seventh Framework Program EUROSPIN (Contract HEALTH-F22009-241498 to K.R.), the German-Israeli Foundation DIP (Grant R03971/1-1 to K.R.), and the Israel Science Foundation (Grant 1003/12 to K.R.). We thank Jean A. Boutin (Pharmacologie Moleculaire et Cellulaire, Institut de Recherches Servier for the kind gift of QR2 inhibitors, S29434, and S26695); Vahram (Harry) Haroutunian and Joeseph Buxbaum (Mt. Sinai School of Medicine, New York, New York) for the human brain tissue; members of the K.R. laboratory for support, specifically David Levitan and Chinnakkaruppan Adaikkan for the numerous discussions we had regarding this work and their invaluable advice; and Paul Skehel and Shunit Gal-Ben-Ari for critical review of the manuscript.

The authors declare no competing financial interests.

Correspondence should be addressed to Dr. Kobi Rosenblum, Sagol Department of Neurobiology, Center for Gene Manipulation in the Brain, University of Haifa, Haifa 3498838, Israel. E-mail: kobir@psy.haifa.ac.il.

DOI:10.1523/JNEUROSCI.1170-15.2015

Copyright $\odot 2015$ the authors $\quad 0270-6474 / 15 / 3515568-14 \$ 15.00 / 0$ and long-term memories, which can guide animal behavior for many hours up to a lifetime (Kandel, 2001; Johansen et al., 2011; Guzman-Karlsson et al., 2014; Rosenberg et al., 2014). It is suggested that experiences important for an animal's survival create more stable memories in evolutionary-dependent mechanisms (Johansen et al., 2011; Gal-Ben-Ari and Rosenblum, 2011). The underlying mechanisms controlling memory strength are not well understood. Here, we used taste learning to identify constraints imposed on cortical-dependent learning, the brain area assumed to store long-term memories in the mammalian brain (Kolb and Tees, 1990; Rosenblum et al., 1993; Kandel et al., 2000).

The sense of taste is critical in allowing the animal to differentiate between nutritious and harmful food such as poison. Animals, including humans, are naturally neophobic; they tend to initially consume only small amounts of any novel tastant. Animals may develop a long-term memory of a given novel taste, including its safety, after exposure to even a small amount of the taste (Bures et al., 1998; Inberg et al., 2013). 
Novel taste learning is correlated with prolonged release of acetylcholine (Ach) in the insular cortex (IC) (Naor and Dudai, 1996; Miranda et al., 2000). ACh activates nicotinic and muscarinic receptors and the latter are necessary for novel taste learning (Gutiérrez et al., 2003). The cholinergic system plays a role in various cognitive processes including attention, learning, and memory (Giovannini et al., 2001; Bermúdez-Rattoni, 2004) and is essential for learning by responding to the novelty of the stimulus (Ranganath and Rainer, 2003). The cholinergic system also play a role in neurological diseases involving dementia, such as Alzheimer's disease (AD) (Mesulam et al., 1987). Pharmaceuticals used to treat dementia often contain a cholinesterase inhibitor (Davis and Mohs, 1982).

After a preliminary screening for differential mRNA expression in the IC of animals that learned negative or positive tastes, we focused our study on quinone reductase 2 (QR2), one of two primary quinone reductases found in mammals: QR1 and QR2 (or NQO1 and NQO2, respectively). QR2 is expressed throughout the cortex and hippocampus and is primarily found in the cytoplasm of neurons (Benoit et al., 2010). Interestingly, the majority of the research relating to the interaction between QR2 and disease has been focused on its role in skin cancer and malaria (Postma et al., 1996; Graves et al., 2002; Iskander et al., 2004; Kwiek et al., 2004). Recently, QR2 overexpression has been correlated with a variety of neurological diseases, including schizophrenia (Harada et al., 2003; Wang and Jaiswal, 2004), Parkinson's disease (Harada et al., 2001; Wang and Jaiswal, 2004), and AD (Hashimoto and Nakai, 2011). In this study, we hypothesize that QR2 expression is a memory constraint that can be removed behaviorally by novel experience or pharmacologically by acetylcholine esterase inhibitors.

\section{Materials and Methods}

Subjects

Adult male Wistar Hola rats (WSH; Harlan Laboratories), 10-16 weeks old, were used for this study. They were maintained on a $12 \mathrm{~h} \mathrm{light/dark}$ cycle and all experiments were performed during the light phase. The rats had ad libitum access to standard rat chow and water unless otherwise indicated. The procedures were performed in strict accordance with the University of Haifa regulations and the National Institutes of Health guidelines (NIH publication number 8023).

\section{Behavioral procedures}

In all behavioral paradigms, animals were housed separately in a new cage. Food was available ad libitum. In all learning paradigms, the rats were water deprived for a period of $24 \mathrm{~h}$. This was followed by $3 \mathrm{~d}$ of restriction during which the rats received 2 pipettes each containing 10 $\mathrm{ml}$ of water for $20 \mathrm{~min}$ per day. The fourth day was the learning day.

Novel taste learning. On the learning day, the experimental group received 2 pipettes, each containing $10 \mathrm{ml}$ of a novel taste solution, saccharin $(0.1 \% \mathrm{w} / \mathrm{v}$; Sigma-Aldrich), for $20 \mathrm{~min}$. The control group received two pipettes, each containing $10 \mathrm{ml}$ of water for $20 \mathrm{~min}$. After exposure to the novel taste, the animals went through $2 \mathrm{~d}$ of water restriction during which they received 2 pipettes each filled with $10 \mathrm{ml}$ of water for $20 \mathrm{~min}$ each day. On the third day, all of the rats were given two pipettes, each containing $10 \mathrm{ml}$ of water, as well as two pipettes, each containing $10 \mathrm{ml}$ of the novel taste solution previously given to the experimental group. Comparisons between the groups were conducted through the evaluation of the preference indexes (PIs). The PI was calculated by the following equation: [(total novel taste solution ingested/(novel taste solution ingested + water ingested) $) * 100]$. The higher the PI, the more the rat preferred the novel taste (Rosenblum et al., 1993).

Conditioned taste aversion. On the learning day, the experimental group received 2 pipettes, each containing $10 \mathrm{ml}$ of a novel taste solution, saccharin $(0.1 \% \mathrm{w} / \mathrm{v})$, for $20 \mathrm{~min}$. The control group received two pipettes, each containing $10 \mathrm{ml}$ of water, for $20 \mathrm{~min}$. Forty minutes after the drinking period, both groups were injected with $\mathrm{LiCl}$ (prepared in double-distilled water (DDW, 2\% bodyweight, i.p.).

After the learning day, the animals went through $2 \mathrm{~d}$ of water restriction during which they received two pipettes, each filled with $10 \mathrm{ml}$ of water, for $20 \mathrm{~min}$ each day. On the third day, all of the rats were given two pipettes each containing $10 \mathrm{ml}$ of water, as well as two pipettes each containing $10 \mathrm{ml}$ of the novel taste liquid previously given to the experimental group. Comparisons between the groups were conducted through the evaluation of the aversion indexes (AIs). The AI was calculated by the following equation: [(total water ingested/(novel taste solution ingested + water ingested)) $* 100]$. The higher the AI, the more the rat learned the negative association of the taste.

\section{Materials}

Vehicle. All pharmacological agents were dissolved in physiological saline, prepared in-house by dissolving $\mathrm{NaCl}$ (Sigma-Aldrich) in DDW $(0.9 \% \mathrm{w} / \mathrm{v})$. The physiological saline was injected to the control animals in all experiments in which the test group $(\mathrm{s})$ was injected with a pharmacological agent. The same volume of the vehicle was injected as the pharmacological agent.

QR2 inhibitors. The QR2 inhibitors S29434 and S26695 were a kind gift from Dr. Jean A. Boutin (Pharmacologie Moleculaire et Cellulaire, Institut de Recherches Servier). The inhibitors were dissolved in dimethyl sulfoxide (Sigma-Aldrich) and then added to physiological saline. The final concentration of dimethyl sulfoxide in the physiological saline was $5 \%$. These inhibitors were injected ( $8 \mathrm{mg} / \mathrm{kg}$, i.p.) $1 \mathrm{~h}$ before the learning process (Gutiérrez et al., 2003).

Muscarinic acetylcholine receptor antagonist. (-)-Scopolamine hydrochloride (Sigma-Aldrich), a muscarinic acetylcholine receptor (mAChR) antagonist, was dissolved in DDW and added to physiological saline. Scopolamine ( $2 \mathrm{mg} / \mathrm{kg}$, i.p.) was injected $1 \mathrm{~h}$ before the learning process (Berger, 1972).

Cholinesterase inhibitor. Eserine (physostigmine; Sigma-Aldrich), a cholinesterase inhibitor, was dissolved in DDW and added to physiological saline and injected ( $1 \mathrm{mg} / \mathrm{kg}$, i.p.) $1 \mathrm{~h}$ before the learning process (Warburton, 1969; Baratti et al., 1979; Singh and Parle, 2003).

\section{Biochemical procedures}

Tissue extraction. After the learning protocol, the IC, identified according to the rhinal fissure and the medial cerebral artery, was excised, immediately snap-frozen in liquid nitrogen, and stored at $-80^{\circ} \mathrm{C}$.

$m R N A$ quantification. For RNA extraction, the RNeasy lipid tissue kit (QIAGEN) was used according to the manufacturer's instructions. RNA concentration and purity were evaluated using Nanodrop (Thermo Scientific Nanodrop 2000).

A high-capacity reverse transcription kit $(\mathrm{ABI})$ was used according to the manufacturer's instructions for cDNA synthesis. The reaction was performed in a total volume of $20 \mu \mathrm{l}$ using $1 \mu \mathrm{g}$ of RNA as a template.

qRT-PCR was performed in a total volume of $10 \mu \mathrm{l}$ using $10 \mathrm{ng}$ of cDNA and the following TaqMan assays (Applied Biosystems): QR2 (Rn01434728_g1), NAD(P)H dehydrogenase quinone 1 (NQO1) (RN 00566528_m1), glyceraldehyde-3-phosphate dehydrogenase, GAPDH (Rn01775763_g1). Reactions were performed in accordance with the manufacturer's instructions.

Real-time PCR analysis was performed using the PCR System STEP-ONE plus (Applied Biosystems). Relative mRNA levels were calculated using the $\triangle \Delta \mathrm{C}_{\mathrm{t}}$ method using GAPDH as a normalizing gene as follows:

$\Delta \Delta C_{\mathrm{t}}=\left[\left(C_{\mathrm{t}}\right.\right.$ (gene of interest $\left.)-\mathrm{Ct}(\mathrm{GAPDH})\right)$ of the untreated group $]-\left[\left(C_{\mathrm{t}}\right.\right.$ (gene of interest $\left.)-\mathrm{Ct}(\mathrm{GAPDH})\right)$ of the treated group $]$ and the fold increase $=2^{-\Delta \Delta C t}$.

Microarray experiment and data analysis. Affymetrix GeneChip RaGene 1.1 ST v1 array was used for gene expression analysis in accordance with the manufacturer's instructions (Affymetrix). Microarray analysis was performed on CEL files using the Partek Genomics Suite. Data were normalized and summarized with the robust multiaverage method and expression intensities were obtained in $\log 2$ scale. One-way ANOVA was applied. Venn diagrams were formed using the Partek Genomics Suite. Only genes that showed a strong trend of being differ- 
entially expressed with a fold change difference of $\geq 1.25$ were represented in the Venn diagrams.

Micro-infusion. Rats were anesthetized with Equithesin $(0.45 \mathrm{ml} / 100 \mathrm{~g}$; $2.12 \% \mathrm{w} / \mathrm{v} \mathrm{MgSO}_{4}, 10 \% \mathrm{v} / \mathrm{v}$ ethanol, $39.1 \%$ v/v 1,2,-propranolol, $0.98 \%$ $\mathrm{w} / \mathrm{v}$ sodium pentobarbital, and $4.2 \% \mathrm{w} / \mathrm{v}$ chloral hydrate) and restrained in a stereotactic apparatus (Stoelting) and guide stainless steel cannulae (23 gauge) were implanted bilaterally into the GC (anterior-posterior, $1.2 \mathrm{~mm}$; dorsal-ventral, $6.5 \mathrm{~mm}$; lateral, $5.5 \mathrm{~mm}$ ) (Sano et al., 2014). The cannulae were positioned using acrylic dental cement and secured by two skull screws. A stylus was placed in the guide cannulae to prevent clogging. After surgery, animals were allowed to recover for 1 week before being subjected to experimental manipulations. On the experiment day, the stylus was removed from the guide cannula and a 28 gauge injection cannula extending from the tip of the guide cannula was placed carefully. The injection cannula was connected via PE20 tubing to a Hamilton microsyringe driven by a micro-infusion pump (CMA/100; Carnegie Medicine). Micro-infusion was performed bilaterally in $1 \mu$ l of inhibitor per hemisphere delivered over $1 \mathrm{~min}$. The injection cannula was left in position before withdrawal for an additional $1 \mathrm{~min}$ to minimize dragging of the injected liquid along the injection tract. To avoid lateral bias, order of hemisphere injection was randomized. After the microsurgery, animals were injected with $0.01 \mathrm{ml} / 100 \mathrm{~g}$ of amoxicillin (15\% bodyweight s.c.) daily for $3 \mathrm{~d}$ and allowed to recuperate for 1 week.

Lentiviral vectors and infection. Three clones containing short hairpin RNA (shRNA) constructs directed against QR2, as well as a scrambled shRNA sequence clone, were obtained from Sigma-Aldrich. The clones were chosen based on a BLAST evaluation for matching and specificity to QR2. After further evaluation of these clones as explained below, the TRCN0000305394 clone was selected for further use. The clone sequence was as follows: $5^{\prime}$-CCGGCAGTCACTGTGTCTGATTTATCTCGA GATAAATCAGACACAGTGACTGTTTTTG-3'.

The U6-promoter-regulated shRNA sequences were each subcloned into the lentiviral (LV) plasmid pFUGW for coexpression of shRNA driven by the U6 promoter with EGFP under control of the CMV promoter. The LV was produced according to the method described by Lois et al. (2002).

In brief, the cassettes containing the shRNA sequences, EGFP, and the promoters were transfected into the 293FT cell line (Invitrogen) and allowed to express and form particles for $48 \mathrm{~h}$. This was then collected and then purified and concentrated though a series of centrifugation steps. The resulting LVs were then dissolved in sterile PBS and stored at $-80^{\circ} \mathrm{C}$ until use.

LVs were stereotaxically injected into the IC in anesthetized rats using a 23 gauge stainless steel injector attached to a stereotactic infusion pump, rats received bilateral $1 \mu$ l of LVs over 10 min per hemisphere. The injector was left in place for 5 min before and after infusion to minimize fluid retraction. After the microsurgery, animals were subcutaneously injected with $0.01 \mathrm{ml} / 100 \mathrm{~g}$ of amoxicillin and given $7 \mathrm{~d}$ to recover and for the LVs to express.

Generation of primary cortical cell cultures and evaluation of shRNA clones. Cortical cell cultures were prepared as described previously (Ryan et al., 1993). Briefly, cortex regions were dissected from 1- to 2-d-old WSH rats, dissociated by trypsin treatment and DNase treatment, followed by trituration with a siliconized Pasteur pipette, and then plated onto 6-well plates coated with polyethylenimine (Sigma-Aldrich). Seeding culture medium consisted of MEM (Invitrogen without phenol red for microscopy), $20 \mathrm{~mm}$ glucose (Sigma-Aldrich), gentamycin sulfate 5 $\mu \mathrm{g} / \mathrm{ml}$ (Sigma-Aldrich), $25 \mathrm{mg} / \mathrm{L}$ insulin (Sigma-Aldrich), $2 \mathrm{~mm}$ L-glutamine (Sigma-Aldrich), 5-10\% fetal bovine serum (SigmaAldrich), and $10 \%$ NU serum (Becton Dickinson Labware). Cultures were maintained at $37^{\circ} \mathrm{C}$ in a $95 \%$ air $/ 5 \% \mathrm{CO}_{2}$ humidified incubator and culture medium was replaced to feeding medium containing MEM $(\sigma)$ $20 \mathrm{~mm}$ glucose (Sigma-Aldrich), gentamycin sulfate $5 \mu \mathrm{g} / \mathrm{ml}$ (SigmaAldrich), and 2\% B-27 (Invitrogen), and $0.5 \mathrm{~mm}$ L-glutamine supplement (Invitrogen) every $7 \mathrm{~d}$.

The clones were then each evaluated in the primary cortical cell cultures. After the application of the three different clones, as well as a scrambled version that acted as a control, the cultures were analyzed for QR2 mRNA expression. We also evaluated changes in NQO1 mRNA expression as a way of evaluating specificity. None of the clones led to changes in NQO1 mRNA expression levels and all led to a decrease in QR2 mRNA expression levels. We selected the clone that was the most efficient, TRCN0000305394.

Perfusion and fixation. The animals were deeply anesthetized with an overdose $(10 \mathrm{mg} / 100 \mathrm{~g})$ of sodium pentobarbital and then perfused through the left ventricle, first with ice-cold $0.01 \mathrm{~m}$ PBS solution and then with a fixative containing $4 \%$ paraformaldehyde (PFA) in $0.01 \mathrm{M} \mathrm{PBS,} \mathrm{pH}$ 7.4 , for $15 \mathrm{~min}$. The brains were removed and postfixed in the same solution overnight. They were then stored in a $30 \%$ sucrose and $1 \%$ PFA in $0.01 \mathrm{M}$ PBS for $4 \mathrm{~d}$. After postfixation, brains were frozen at $-80^{\circ} \mathrm{C}$ until sectioning by cryostat.

Immunohistochemistry. Coronal $30 \mu \mathrm{m}$ brain sections from +1.2 bregma were sliced with a cooled cryostat (Leica CM 1850). Slices were washed twice with $0.01 \mathrm{M}$ PBS, and nonspecific antibody binding was blocked with $1.2 \%(\mathrm{w} / \mathrm{v})$ normal goat serum (NGS) in $0.01 \mathrm{~m}$ PBS containing $0.5 \%$ Triton $\mathrm{X}-100$ for $3 \mathrm{~h}$ at room temperature (RT). The sections were incubated with monoclonal mouse anti-NeuN antibody (Millipore) diluted 1:100 in $0.01 \mathrm{M} \mathrm{PBS}$ and $0.2 \%(\mathrm{w} / \mathrm{v})$ NGS solution for $24 \mathrm{~h}$ at $4^{\circ} \mathrm{C}$ with gentle shaking. After 3 washes in $0.01 \mathrm{~m}$ PBS, sections were incubated in secondary antibody Alexa Fluor 594 goat anti-mouse $\operatorname{IgG}(\mathrm{H}+\mathrm{L})$ antibody (Invitrogen) in 1:400 dilution prepared in $0.2 \%$ $(\mathrm{w} / \mathrm{v})$ normal goat serum in $0.01 \mathrm{~m}$ PBS for $2 \mathrm{~h}$ at RT. After 2 PBS $0.01 \mathrm{~m}$ washing steps, nuclei were stained by incubating the sections with Hoechst 33258 diluted 1:5000 in PBS 0.01 M. Sections were mounted onto Super Frost-coated slides with Slow Fade antifade medium (Invitrogen). Slides were kept in the dark at $4^{\circ} \mathrm{C}$ before image acquisition and analysis.

Human samples. Samples were received from the Brain Bank at Mt. Sinai School of Medicine (New York). The study included postmortem cross-sectional data from 39 nursing home residents with clinical dementia ratting (CDR) scale scores ranging from CDR 0 (no dementia, $n=11$ ) to CDR1 (mild dementia, $n=28$ ). Brain samples were taken from the superior frontal gyrus $(\mathrm{Bm} 8)$.

$m R N A$ quantification of the human samples. For the human samples, total RNA $(1 \mu \mathrm{g})$ from the syperior frontal gyrus (Bm8) was reverse transcribed using ImpromII (Promega) with random hexamers (MBI Fermentas). Real-time PCR was performed in a total volume of $10 \mu \mathrm{l}$ using TaqMan universal PCR master mix (Applied Biosystems) using 2 $\mu \mathrm{l}$ of cDNA and gene-specific "assay on demand" TaqMan reactions (Applied Biosystems). Real-time PCRs were performed in duplicate using the ABI PRISM StepOne plus Sequence Detector (Applied Biosystems) under the following conditions: $50^{\circ} \mathrm{C}$ for $2 \mathrm{~min}, 95^{\circ} \mathrm{C}$ for $10 \mathrm{~min}$, and 40 cycles of $95^{\circ} \mathrm{C}$ for $15 \mathrm{~s}$ and $60^{\circ} \mathrm{C}$ for $1 \mathrm{~min}$. Threshold cycle (Ct) values of the examined gene of interest (QR2, Hs01056948_m1) were normalized to the $\mathrm{Ct}$ values of two housekeeping genes GUSB and IPO8 (Hs99999908-m1, Hs00183533-m1 respectively) in the AD and aged matched control groups. Relative mRNA quantities were calculated for each sample separately using the $2^{-\Delta \mathrm{Ct}}$ formula and mRNA RQ for the test group (AD) was calculated using the $2^{-\Delta \Delta C t}$ formula. Statistical analysis were performed using $2^{-\Delta \mathrm{Ct}}$ values.

\section{Statistical analysis}

Results are expressed as means \pm SEM. For statistical analysis, after checking for normality, we used the unpaired Student's $t$ test, Levene's test for homogeneity of variances, one-way ANOVA test with Fisher's least significance difference (LSD) post hoc test, and repeated-measures ANOVA. Significance was determined using an $\alpha$ level of 0.05 . We used the SPSS Statistics version 20 program to perform the statistical analysis.

\section{Results}

\section{CTA learning leads to a reduction in QR2 mRNA in the IC}

To identify transcriptional changes after associative taste learning, we used the conditioned taste aversion (CTA) paradigm, subserved by the IC Fig. 1A; (Gal-Ben-Ari and Rosenblum, 2011; Sano et al., 2014), combined with microarray technology (Affymetrix rat gene 1.1 st arrays). Among the differentially transcribed mRNAs, we observed an $\sim 50 \%$ reduction in QR2 mRNA 
A
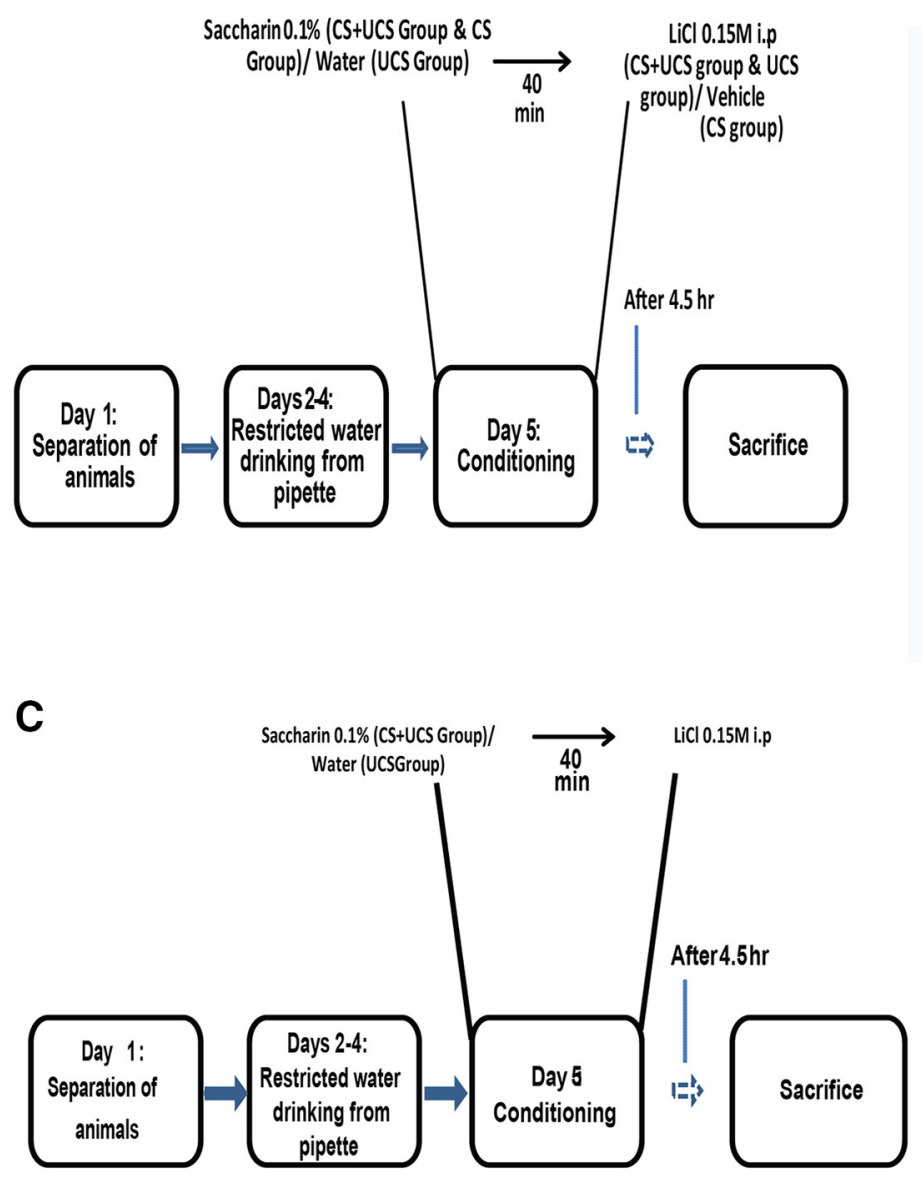

B

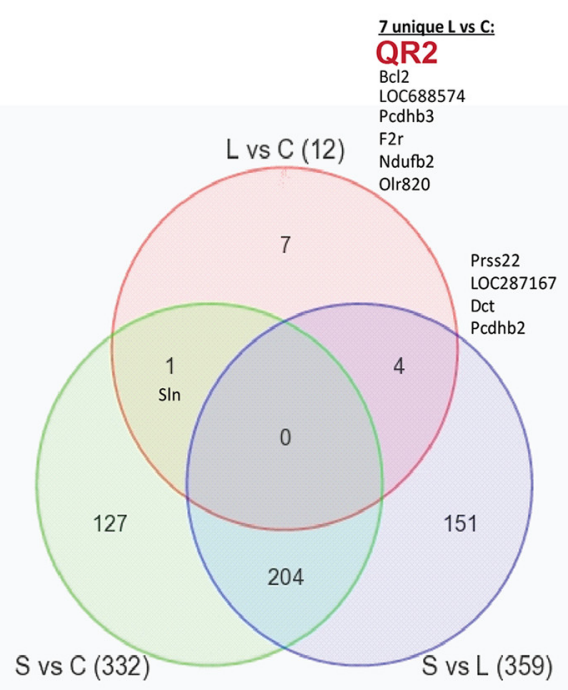

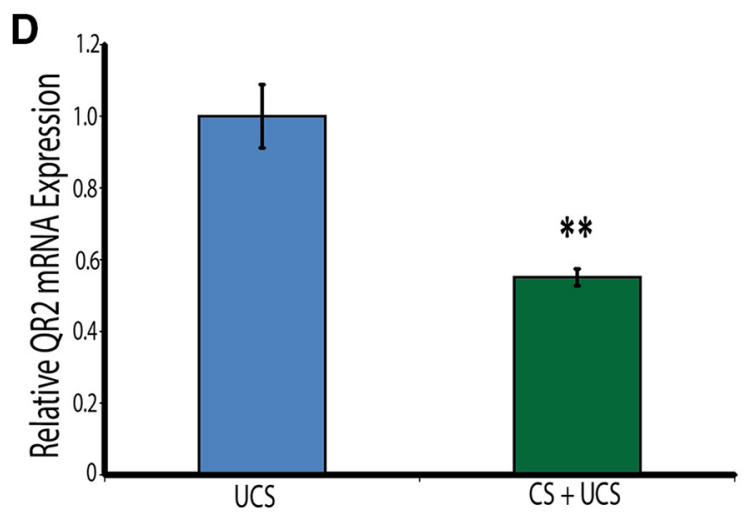

Figure 1. CTA induces a reduction in QR2 mRNA expression in the IC. $A$, Schematic representation of the experiment. The CTA paradigm was performed on rats exposed to saccharin and $\mathrm{LiCl}$ (CS and UCS, respectively) and results were compared with exposure to either saccharin or LiCl. B, Venn diagram representing the differentially expressed genes that passed the cutoff of a fold change of at least 1.25. L, Rats that received only LiCl; S, rats that received only saccharin; C, rats that received saccharin followed by LiCl. QR2 (NQ02) is one of the genes differentially expressed in response to CTA. C, Schematic representation of the CTA learning paradigm. D, Pairing of the saccharin (CS) with the malaise-inducing LiCl injection (UCS) causes a reduction in QR2 mRNA expression in the insular cortex compared with the control group exposed only to the UCS $(n=10)$.

expression in the CTA group compared with the control group exposed to the unconditioned stimulus (UCS; LiCl 0.15 M, i.p.), but not the conditioned stimulus per se (CS; novel taste, saccharin; Fig. 1B).

Having decided to focus on QR2, we validated the microarray results using the $\mathrm{qRT}$-PCR method, observing an $\sim 45 \%$ reduction in QR2 mRNA expression in the IC in the CTA group compared with the control group (Fig. 1C,D; unpaired Student's $t$ test, $\left.t_{10.39}=4.3, n=10, p=0.001\right)$. CTA has both a component of novel taste learning (CS) and a component of associative learning (UCS); we hypothesized that learning a novel taste, as measured by the decrease in neophobic response (i.e., a form of incidental learning that can be measured by increased consumption of a given taste over time) without the negative association component, would lead to a decrease in QR2 mRNA expression in the IC.

\section{Novel taste learning leads to a decrease in QR2 mRNA expression}

We evaluated changes in QR2 mRNA expression in the IC $3 \mathrm{~h}$ after the learning period (Fig. 2A). Consistent with our hypothesis, we observed a decrease in QR2 mRNA expression in the group that learned the novel taste compared with the group that received a familiar taste and did not undergo a learning paradigm (Fig. $2 B$; unpaired Student's $t$ test, $t_{11.767}=4.3, n \geq 10, p=$ $0.001)$. This novel taste learning-induced decrease is both specific to the relevant cortical area (IC, Fig. $2 C$; unpaired Student's $t$ test, $t_{13.89}=0.1, n=8, p=0.887$ ) and to the QR2 oxi-reductase (Fig. $2 D$; unpaired Student's $t$ test, $t_{11.27}=-0.7, n=8, p=0.447$ ) because its homologous enzyme, NQO1, is unaffected.

The novel taste learning-induced decrease in expression levels of QR2 mRNA may result from two possible mechanisms. First, drinking itself leads to higher levels of QR2 mRNA expression in the IC and this increase is prevented when the drinking involves novel taste learning. Second, the novelty component of the novel taste leads to a decrease in QR2 mRNA expression in the IC. To dissociate between these possibilities, we used a group of animals that were water deprived for $24 \mathrm{~h}$ to determine the baseline expression levels of QR2, in addition to the other two groups, which were exposed to either a novel taste or a familiar taste (Fig. $3 A$ ). The results show that QR2 mRNA expression levels in the IC in the animals in the baseline group were similar to those of the animals in the group that received the familiar taste. This suggests that novel taste learning, and not drinking itself, induces a decrease in QR2 mRNA expression in the IC [Fig. 3B; one-way ANOVA $F_{(2,15)}=3.9, n=6, p=0.044$, Fisher's LSD post hoc test 
A

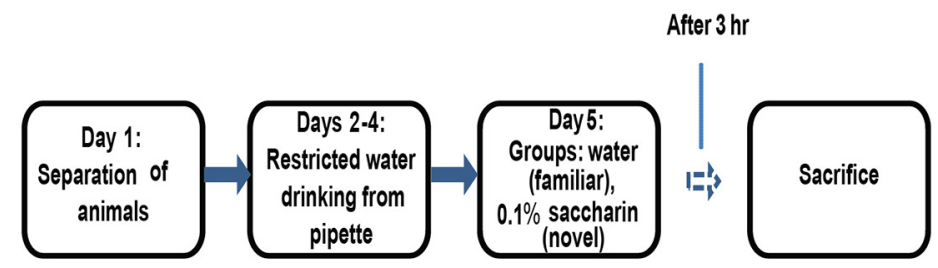

C

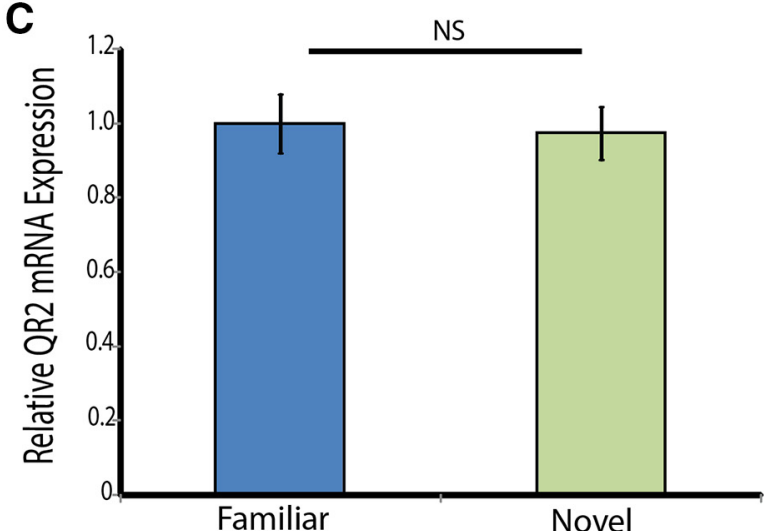

B

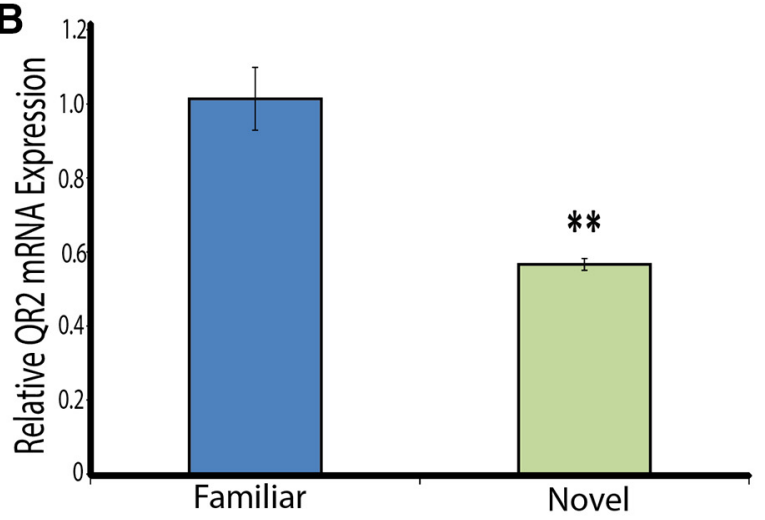

D

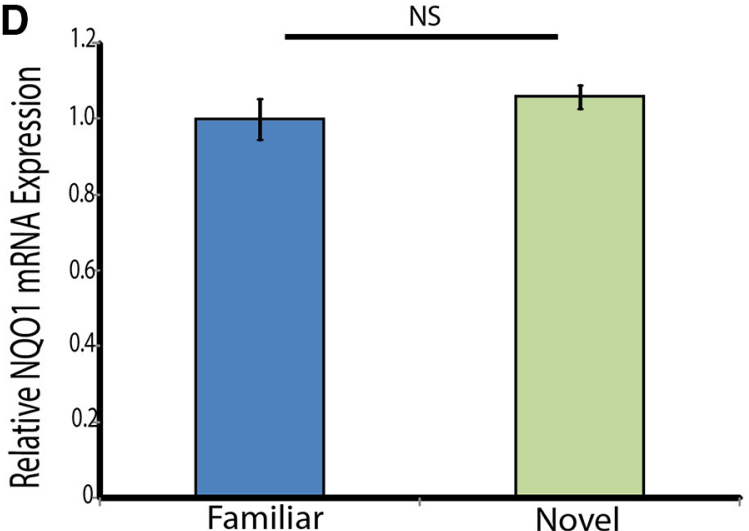

Figure 2. Novel taste learning induces a reduction in QR2 mRNA expression in the IC. $\boldsymbol{A}$, Schematic representation of the novel taste learning paradigm. $\boldsymbol{B}$, Novel taste learning leads to a significant decrease in QR2 mRNA expression in the IC (control, $n=12$; test, $n=10$ ). C, QR2 mRNA expression in the occipital cortex of the animals that underwent the novel taste learning paradigm is unaffected $(n=8)$. $D$, mRNA expression of NQ01 was evaluated in the IC in the animals which underwent the novel taste learning paradigm to determine the effect of novel taste learning on the expression of the other primary oxireductase. The results show that novel taste learning has no effect on NQ01 mRNA expression in the IC ( $n=8)$.

(novel/water deprived) $p=0.029$, Fisher's LSD post hoc test (novel/familiar) $p=0.03$ ]

Novel sensory input is salient information that induces release of different neuromodulators in the relevant brain structure. We hypothesized that the change in expression of QR2 is not due to the specific coding of the chemical information, but rather it specifically reflects the novelty itself. To evaluate this, we used a group that was familiarized to saccharin in addition to the other two groups, which were exposed to either a familiar taste (water) or a single exposure to saccharin (a novel taste; Fig. $3 C$ ). The rats familiarized with saccharin displayed no reduction in QR2 mRNA expression in the IC, demonstrating that the change in expression was due to the learning of the novel information [Fig. $3 D$; one-way ANOVA $F_{(2,15)}=4.6, n=6, p=0.028$, Fisher's LSD post hoc test (novel/familiar saccharin) $p=0.023$, Fisher's LSD post hoc test (novel/familiar water) $p=0.016$ ].

Interestingly, basal levels of QR2 mRNA expression in the IC appear to vary between two fixed floor and ceiling values. Novel taste learning reduces QR2 mRNA expression levels to the lower limit and thus reduces the variance in its expression (Fig. 4). Indeed, Levene's test for homogeneity of variances revealed that the variation in expression levels of QR2 mRNA after novel taste learning was smaller compared with exposure only to the UCS (Fig. $4 A ; F_{(1,18)}=11.7, n=10, p=0.0037$ ), exposure to water as a familiar taste (Fig. $4 B ; F_{(1,20)}=15.5$; control, $n=12$; test, $n=$ $10, p=0.001$ ), water deprivation (Fig. $4 C ; F_{(1,10)}=6.6, n=6$, $p=0.028$ ), or exposure to saccharin as a familiar taste (Fig. $4 D$; $\left.F_{(1,10)}=10.4, n=6, p=0.009\right)$.

\section{QR2 mRNA expression is $\mathrm{mAChR}$ dependent}

As mentioned above, it is well established in the literature that the activation of $\mathrm{mAChR}$ is necessary for learning new information (Aloisi et al., 1997; Merhav and Rosenblum, 2008), including novel taste learning (Mesulam et al., 1987). We corroborated these findings (Fig. $5 A, B$; one-way ANOVA $F_{(2,20)}=46.9$; control, $n=8$; scopolamine, $n=8$; eserine, $n=7, p \ll 0.001$ ), verifying that blocking $\mathrm{mAChR}$ through the use of an $\mathrm{mAChR}$ antagonist, scopolamine $(2 \mathrm{mg} / \mathrm{kg}$, i.p.), prevents the formation of a novel taste memory (Fisher's LSD post hoc test $p \ll 0.001$ ) while increasing the amount of ACh in the system using eserine, an ACh esterase inhibitor and thus a functional $\mathrm{mAChR}$ agonist $(1 \mathrm{mg} / \mathrm{kg}$, i.p.), enhances the memory of a novel taste (Fisher's LSD post hoc test $p=0.022$ ). In addition, it has been shown that inhibiting QR2 activity can lead to partial recovery from the negative effects brought on by the application of scopolamine (an $\mathrm{mAChR}$ antagonist) in old animals, a model for aging (Benoit et al., 2010). We therefore hypothesized that QR2 downregulation after learning novel sensory information in the cortex is $\mathrm{mAChR}$ dependent.

We first examined the effect of preventing mAChR activation (Fig. 5C). These results demonstrate that the reduction in QR2 mRNA expression seen after novel taste exposure (Fisher's LSD post hoc test $p \ll 0.001)$ is precluded through the blockade of $\mathrm{mAChR}$ using scopolamine $(2 \mathrm{mg} / \mathrm{kg}$, i.p.; Fisher's LSD post hoc test, $p=0.001)$, indicating the necessity of mAChR activation to regulate QR2 expression (Fig. 5D; one-way $\operatorname{ANOVA~} F_{(3,41)}=13$; vehicle + familiar taste, $n=21$; vehicle + novel taste, $n=12$; 
A

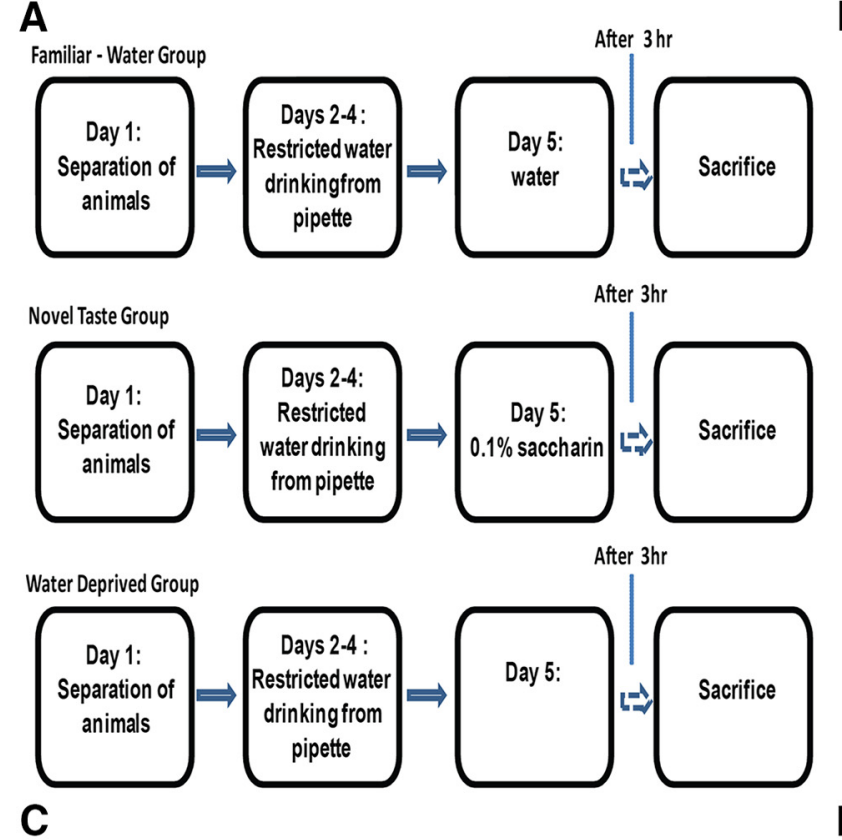

C

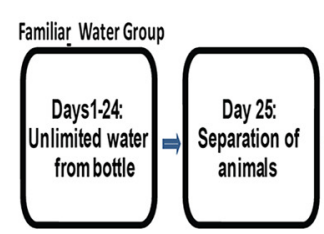

Familiak Saccharin Group

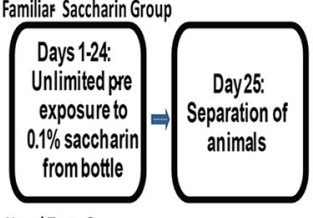

Novel Taste Group

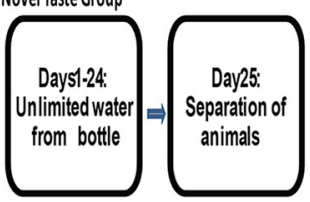

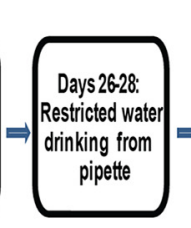
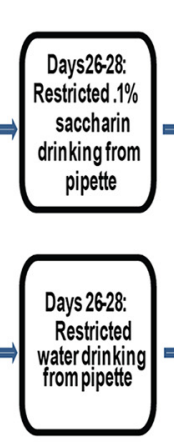
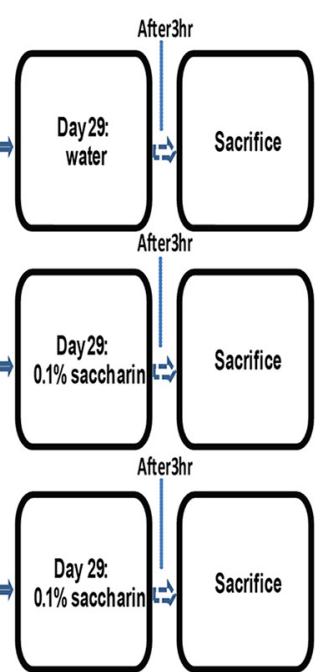

B
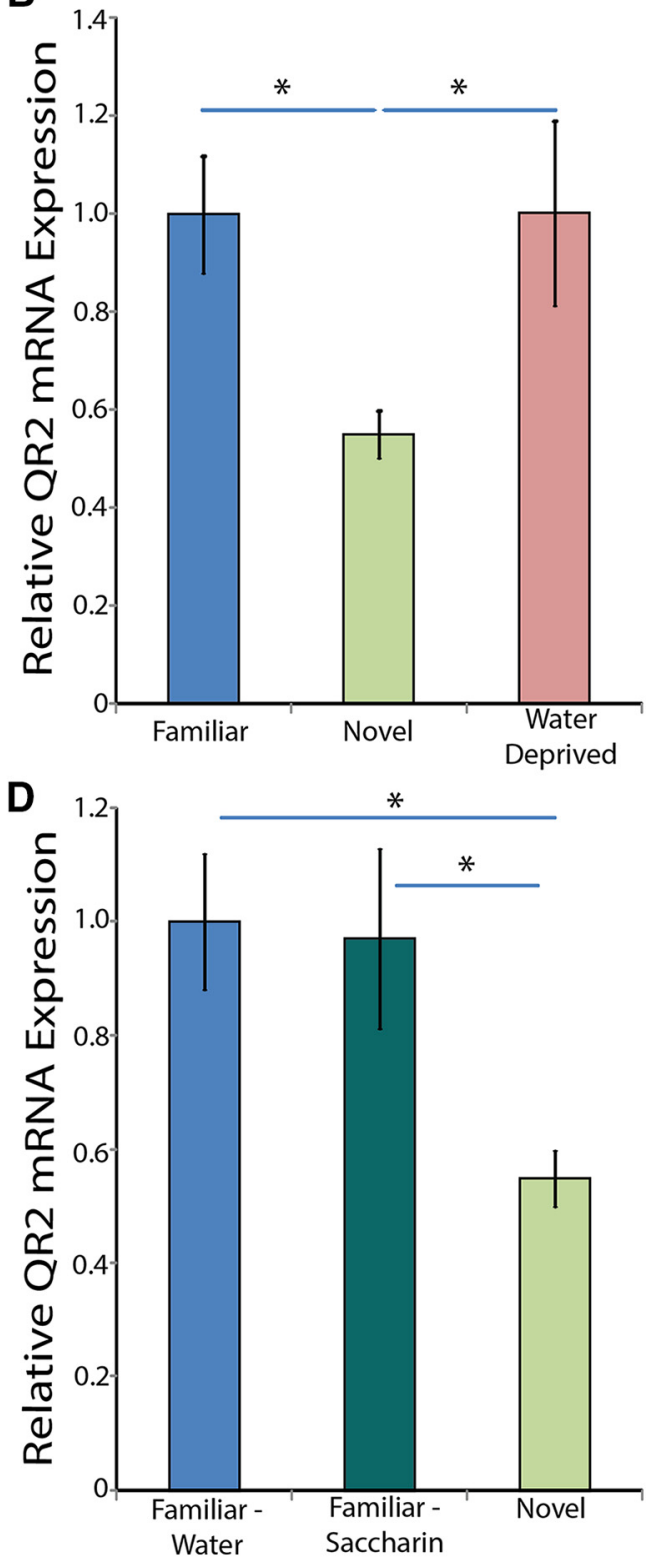

Figure 3. $Q R 2 \mathrm{mRNA}$ expression is inversely correlated with novelty in the IC. $A$, Experimental design to evaluate baseline levels of $Q R 2 \mathrm{mRNA}$ expression in the IC. $\boldsymbol{B}$, Baseline levels of $\mathrm{QR} 2 \mathrm{mRNA}$ in the IC are high and are significantly reduced after exposure to novel taste $(n=6)$. C, Experimental design to evaluate the effect of the familiarization of the animals to saccharin. $\boldsymbol{D}$, Novel taste consumption significantly reduces QR2 mRNA expression, whereas prolonged familiarization with a novel taste results in high QR2 mRNA levels, similar to those of a familiar taste $(n=6)$.

scopolamine + novel taste, $n=6$; eserine + novel taste, $n=6, p$ $\ll 0.001)$. The animals that underwent the novel taste learning paradigm and were given eserine ( $1 \mathrm{mg} / \mathrm{kg}$, i.p.) to increase $\mathrm{ACh}$ availability, did not have further decreased QR2 mRNA expression levels compared with the control group (Fisher's LSD post hoc test $p=0.655$ ). This supports our above observation, indicating that a lower limit of QR2 mRNA expression in the cortex can be achieved pharmacologically by manipulating the $\mathrm{mAChR}$ system or intrinsically after novel taste learning.

We further demonstrated that pharmacologically increasing the amount of ACh in the system through the use of eserine (1 $\mathrm{mg} / \mathrm{kg}$, i.p.) replicates the novel taste learning-induced decrease in QR2 mRNA expression [Fig. 5E, F; one-way ANOVA $F_{(3,44)}=$ 11.1; vehicle + familiar taste, $n=21$; vehicle + novel taste, $n=$ 12; scopolamine + familiar taste, $n=8$; eserine + familiar taste, $n=7, p \ll 0.001$, Fisher's LSD post hoc test (novel + vehicle/familiar + vehicle) $p \ll 0.001$, Fisher's LSD post hoc test (familiar + eserine/familiar + vehicle) $p \ll 0.001]$. Consistent with our findings indicating a floor level for QR2, the animals that did not undergo the novel taste learning paradigm and were given scopolamine did not have higher QR2 mRNA expression levels beyond those in the group that received the vehicle and did not undergo the novel taste learning paradigm, supporting the notion of a ceiling level as well (Fisher's LSD post hoc test $p=0.747$ ).

\section{Decreasing QR2 mRNA expression enhances novel} taste learning

After our results that novel taste learning leads to an mAChRdependent decrease in QR2 mRNA expression in the IC and the well documented role of ACh in memory enhancement (Acquas et al., 1996; Aloisi et al., 1997; Giovannini et al., 2001; Ranganath 
A

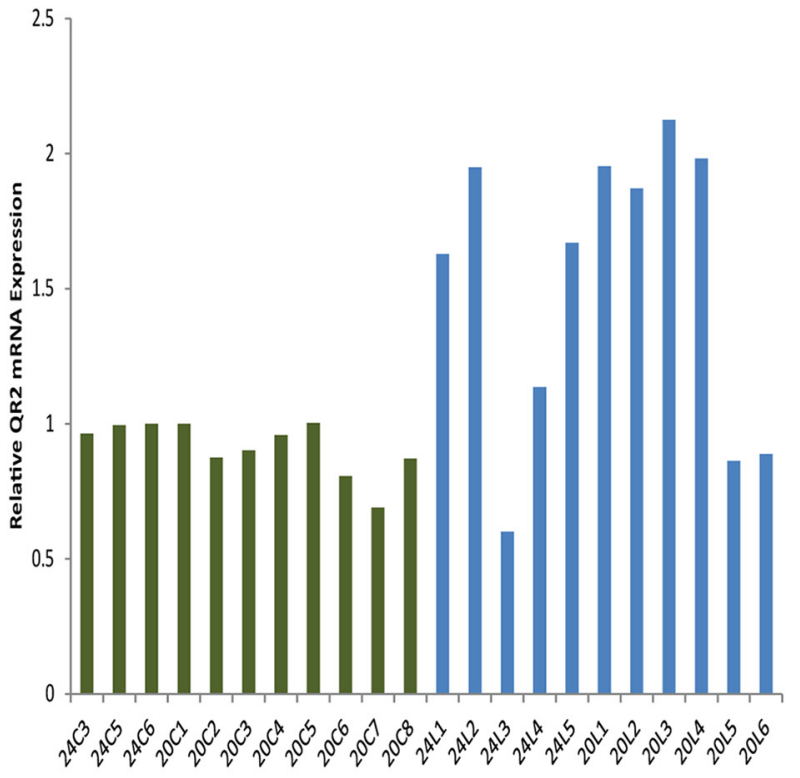

C

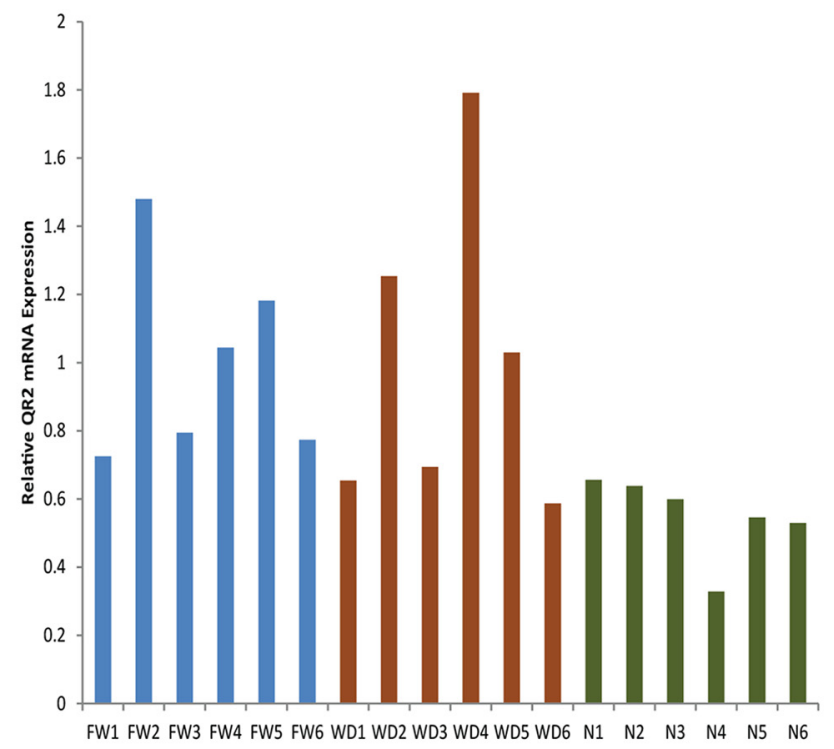

B

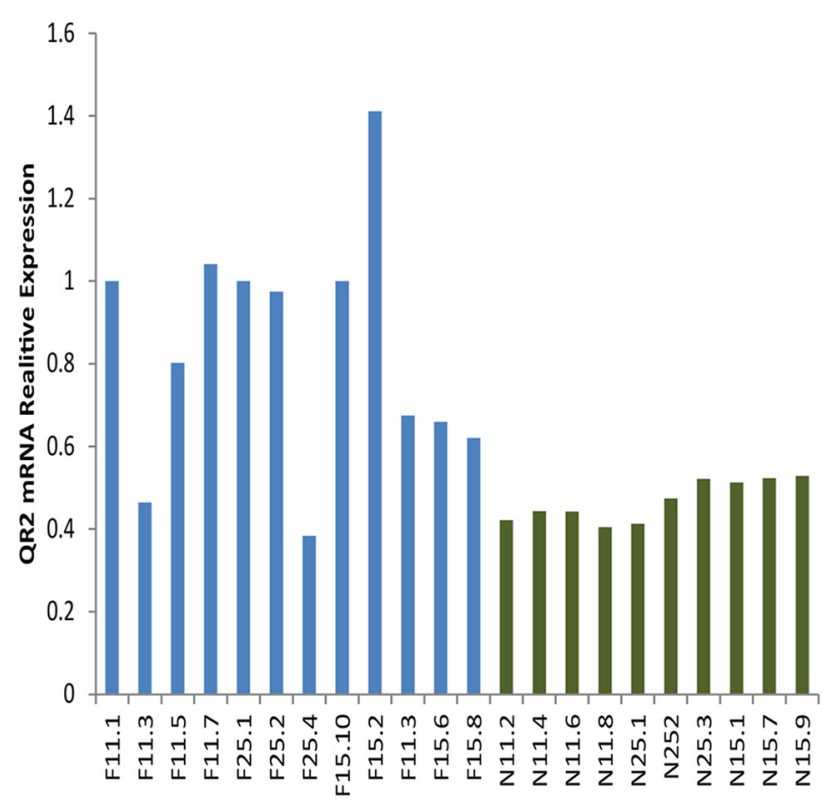

D

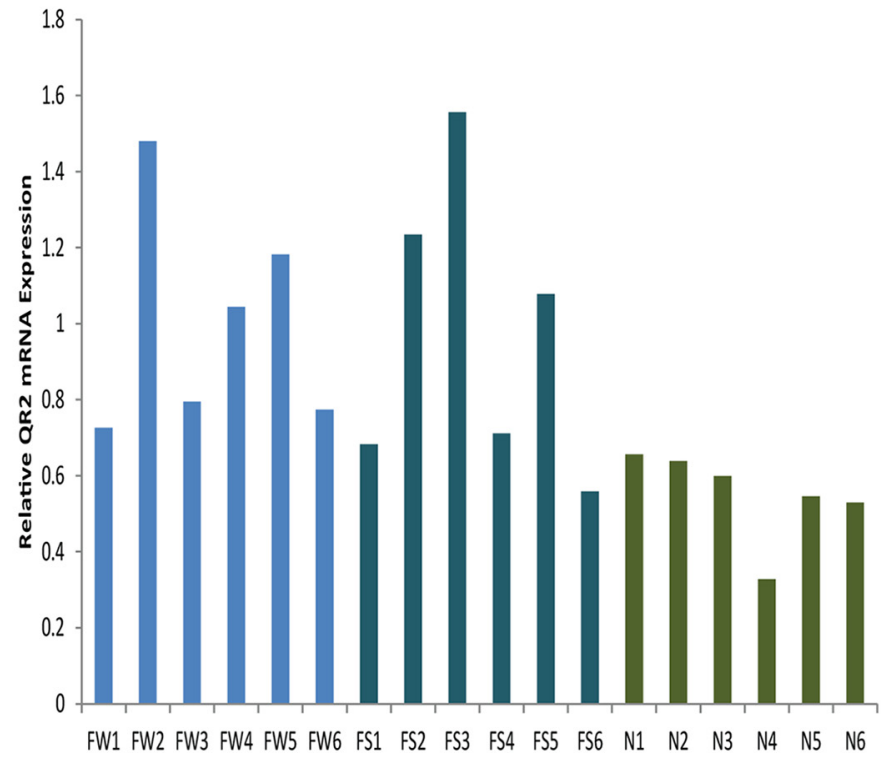

Figure 4. Novel taste learning reduces the variance in QR2 $m R N A$ expression in the IC. To better illustrate the high level of variance of $Q R 2 m R N A$ expression in the IC in the control groups and the resulting reduction in that variance after novel taste learning, we show here QR2 $\mathrm{mRNA}$ expression in the IC from individual animals corresponding to the results shown above in Figures 1 and 2 . As can be seen from $\boldsymbol{A}$, which corresponds to Figure $1 B(n=10) ; \boldsymbol{B}$, which corresponds to Figure $2 B$ (control, $n=12$; test, $n=10$ ); $\boldsymbol{C}$, which corresponds to Figure $3 B$ ( $n=6$ ); and $\boldsymbol{D}$, which corresponds to Figure $3 D(n=6)$; novel taste learning not only leads to a reduction in QR2 mRNA expression in the IC, but also leads to a significant reduction in the variance of QR2 mRNA expression.

and Rainer, 2003; Bermúdez-Rattoni, 2004), we hypothesized that decreasing QR2 expression is a mechanism by which $\mathrm{mAChR}$ exerts its cognitive enhancement effect. Specifically, we hypothesized that decreasing QR2 mRNA expression in the IC would enhance the animal's ability to form taste memories for two reasons. First, we conjectured that if taste learning leads to a decrease in QR2 mRNA expression, then the a priori decrease of QR2 mRNA expression would enhance taste memory. Second, as noted above, QR2 KO mice showed enhanced cognitive function in hippocampal-dependent tasks (Benoit et al., 2010).

To reduce QR2 mRNA expression, we administered a lentiviral vector expressing QR2 shRNA or a scrambled-sequence control vector ( $\mathrm{scr}$ ) stereotaxically into the IC, which we ver- ified through immunohistochemistry (Fig. 6A). In addition, we confirmed that there was a reduction QR2 mRNA expression in the IC in both experiments in which we used the injected animals (Fig. $6 B$; unpaired Student's $t$ test, $t_{11.213}=3.1$, scr: $n=12$, shRNA: $n=10, p=0.009$; Fig. $6 C$; unpaired Student's $t$ test, $t_{9.522}=-3, n=7, p=0.015$ ).

We evaluated the performance of the animals injected with the QR2 shRNA vector, compared with those injected with a scrambledsequence vector, in a novel taste learning paradigm (Fig. $7 A, B$ ). Our results establish that the a priori reduction of QR2 mRNA expression in the IC significantly enhances novel taste learning, but does not affect taste perception (Fig. $7 C$; unpaired Student's $t$ test, $t_{19.911}=$ -3.7, scr: $n=12$, shRNA: $n=10, p=0.001)$. 
A

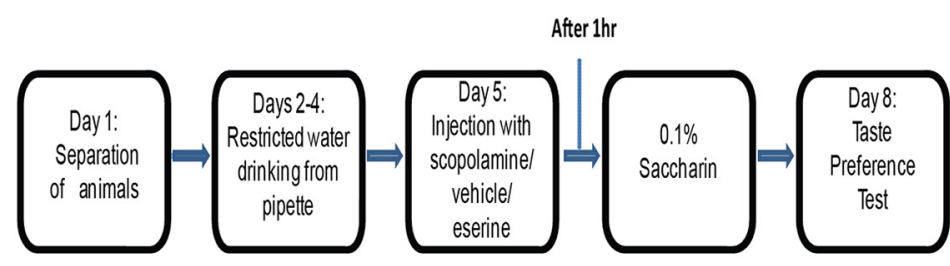

C

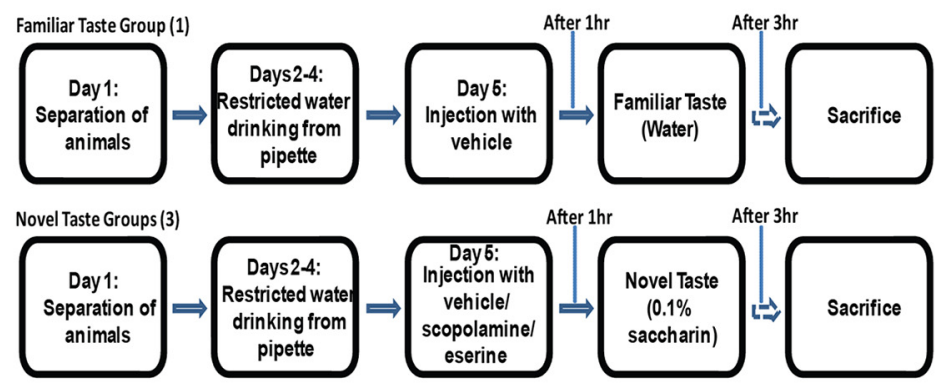

$\mathbf{E}$

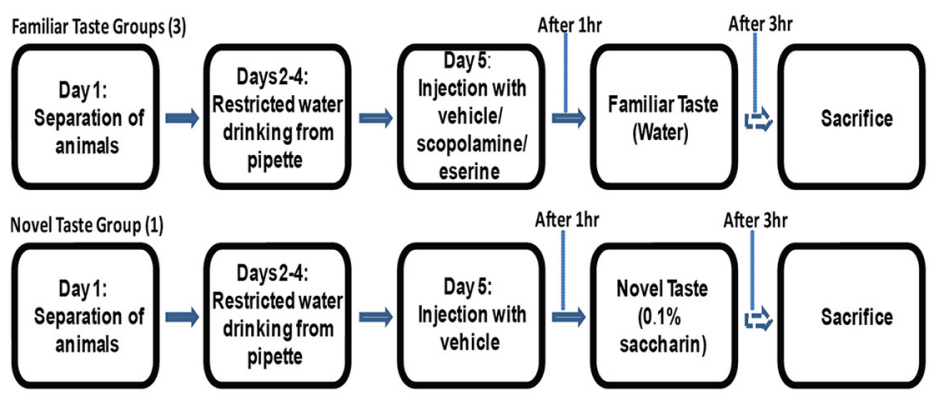

B
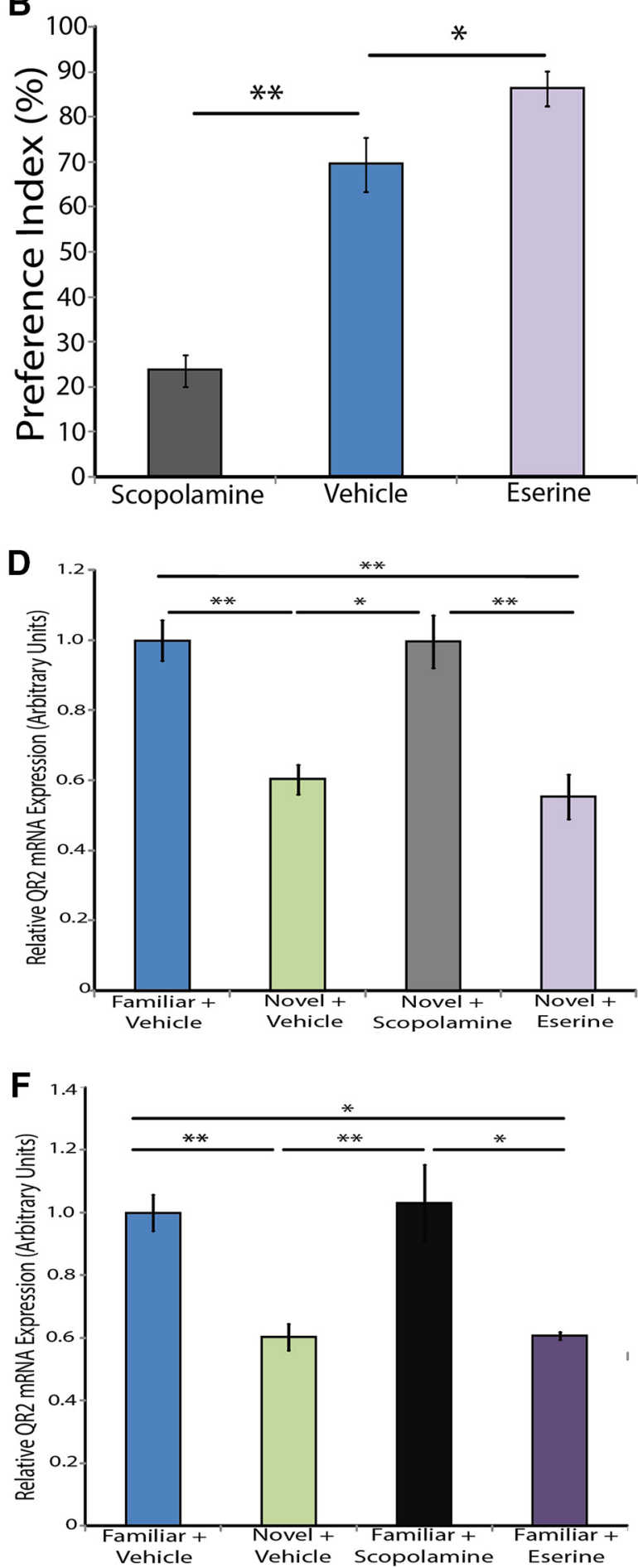

Figure 5. QR2 $\mathrm{mRNA}$ expression is mediated by $\mathrm{mAChR}$ activity. $A$, Schematic representation of the experiment. Rats were injected with scopolamine, eserine, or vehicle before being exposed to a novel taste (saccharin). The animals were then subjected to a taste preference test to assess learning performance. $\boldsymbol{B}$, Blockade of the mAChR during novel taste learning prevents novel taste memory formation, as can be seen from the significantly lower Pl in the group injected with scopolamine compared with the control group. Furthermore, increased $m A C h R$ activation during novel taste learning leads to enhanced learning of the novel taste, as can be seen from the higher Pl in the group injected with eserine compared with the control group (control, $n=8 ;$ scopolamine, $n=$ 8; eserine, $n=7$ ). C Experimental design to determine the effect of preventing mAChR activation on QR2 mRNA expression in the IC after novel taste learning $\boldsymbol{D}$, Injection with $\mathrm{mAChR}$ antagonist scopolamine $(2 \mathrm{mg} / \mathrm{kg}$, i.p.) before exposure to novel taste abolishes the decrease in QR2 mRNA. Administration of $\mathrm{mAChR}$ agonist eserine $(1 \mathrm{mg} / \mathrm{kg}$, i.p.) before exposure to novel taste does not lead to further decrease in QR2 mRNA levels (vehicle familiar, $n=21$; vehicle novel, $n=12$; scopolamine novel, $n=6$; eserine novel, $n=6$ ). $\boldsymbol{E}$, Experimental design to determine the effect of pharmacologically induced activation of $\mathrm{mAChR}$ on QR2 $\mathrm{mRNA}$ expression in the IC. $\boldsymbol{F}$, The novel taste-induced decrease in QR2 $\mathrm{mRNA}$ expression in the insular cortex can be achieved even in the absence of the novel taste in animals injected with eserine. However, administration of scopolamine to animals given a familiar taste does not result in increased QR2 $\mathrm{mRNA}$ levels compared with baseline (vehicle familiar, $n=21$; vehicle novel, $n=12$; scopolamine familiar, $n=8$; eserine familiar, $n=7$ ). 
A
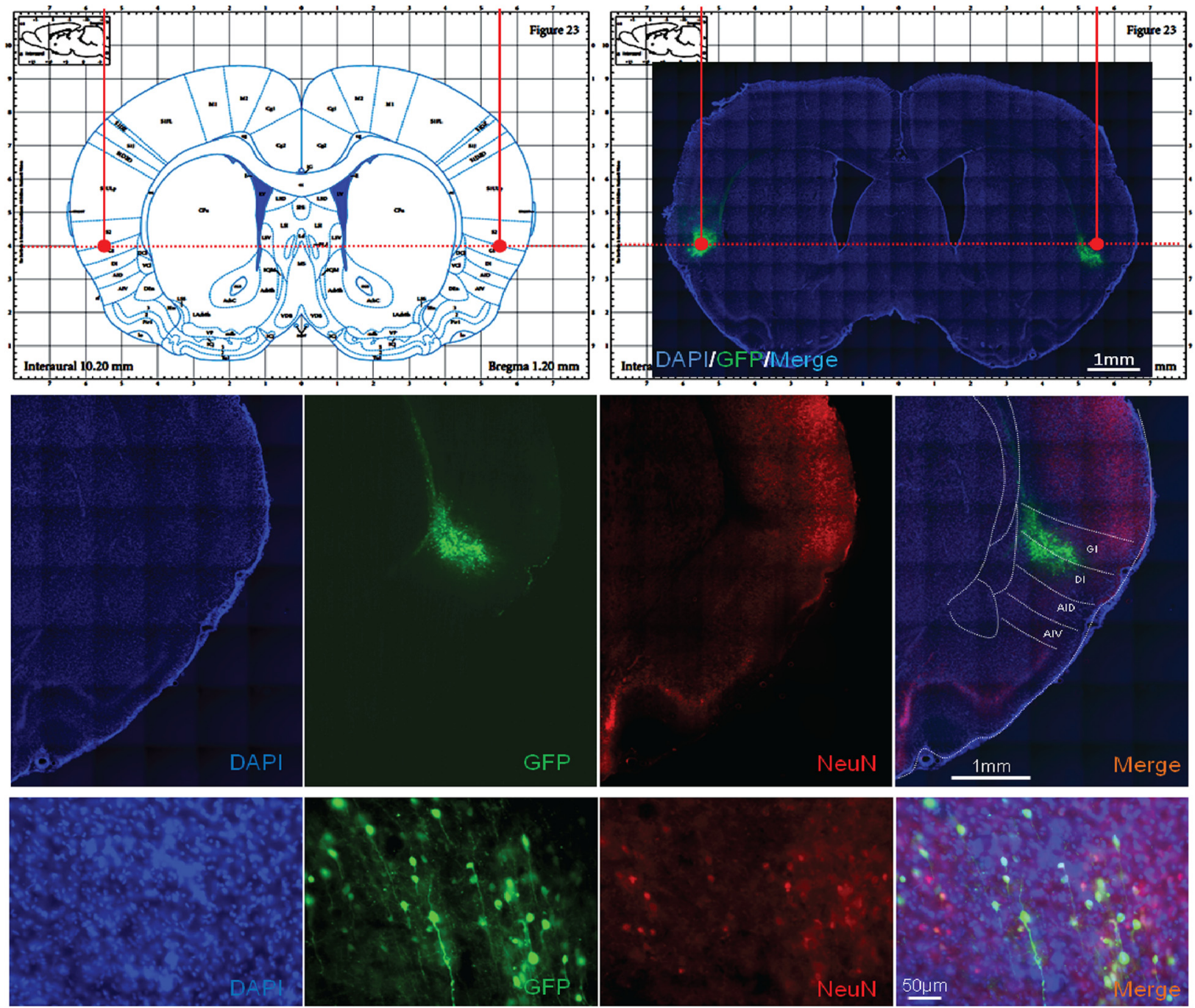

B

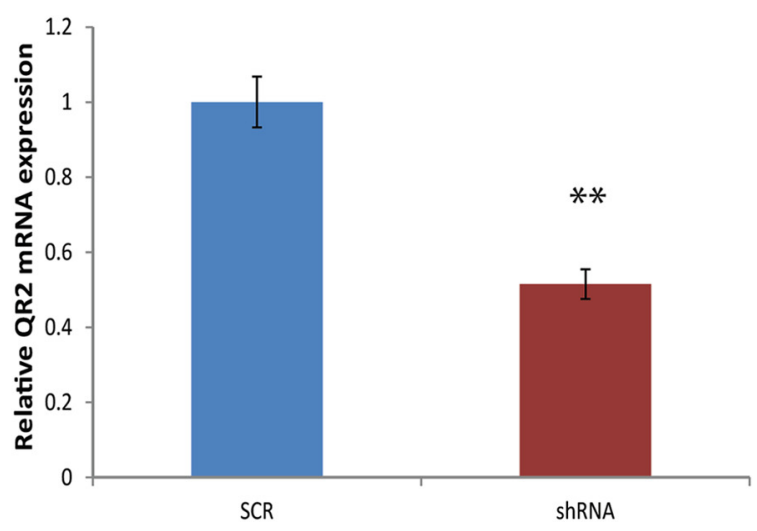

C

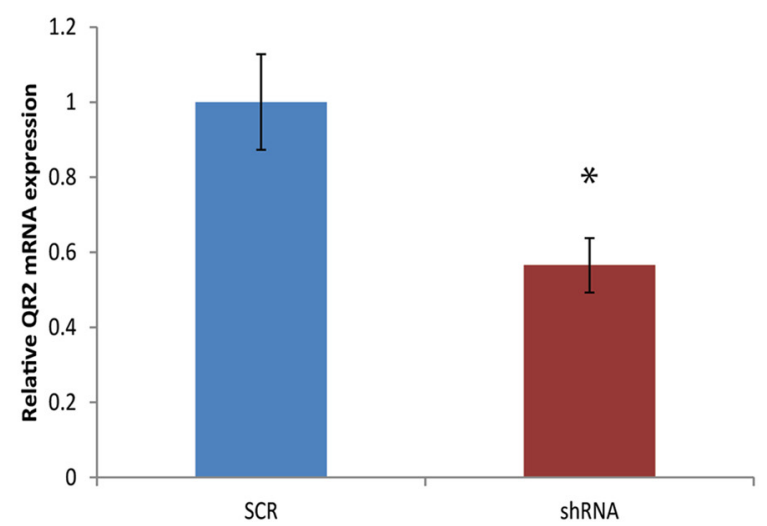

Figure 6. Verification of injection site and the efficacy of the $Q R 2$ shRNA lentiviral vector. $A$, The injection site was verified through immunohistochemistry, allowing detection of the GFP attached to the shRNA. $B$, We verified that the injection of the QR2 shRNA for the experiment described in Figure 7, $B$ and $C$, was successful in reducing QR2 mRNA expression (scrambled, $n=12$; shRNA, $n=10$ ). C, We verified after the experiment described in Figure 7, $F$ and $G$, that the injection of the QR2 shRNA was successful in reducing QR2 mRNA expression (scrambled, $n=12$; shRNA, $n=10$ ).

Inhibiting QR2 activity enhances novel taste learning

Next, we hypothesized that inhibiting QR2 activity would also enhance novel taste learning similarly to inhibition of QR2 mRNA expression with the lentiviral vector. We used two syn- thetic inhibitors, S29434 and S26695 (Benoit et al., 2010; Ferry et al., 2010; Pegan et al., 2011), to evaluate this hypothesis (Fig. 7D). Indeed, animals that received either of the inhibitors performed significantly better in the novel taste learning paradigm [Fig. 7E; 
A

\begin{tabular}{|l|l|l|l|l|l|l|l|}
\hline 5'LTR & RRE CPPT & U6 & QR2 ShRNA & CMV & GFP & WPRE & 3'LTR \\
\hline 5'LTR & RRE cPPT & U6 & SCR hP & CMV & GFP & WPRE & 3'LTR \\
\hline
\end{tabular}

B

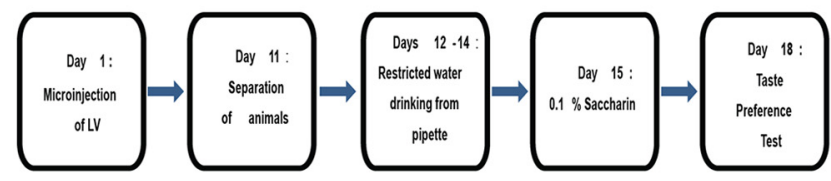

D

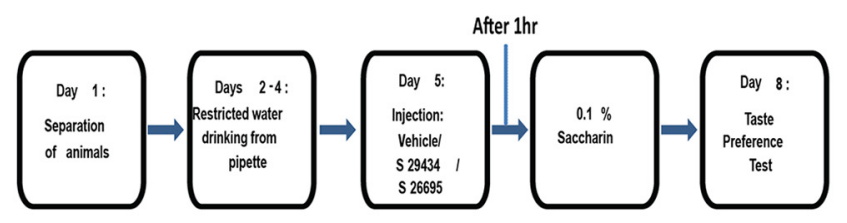

$\mathbf{F}$

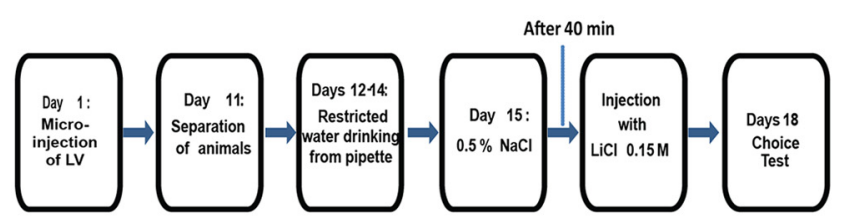

H

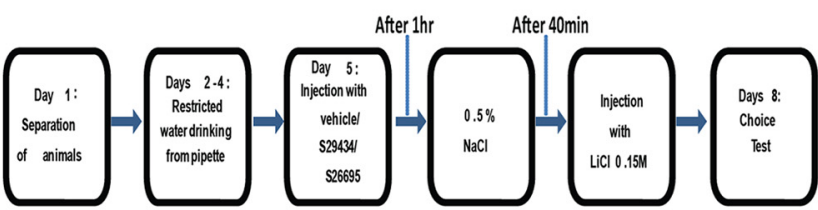

C

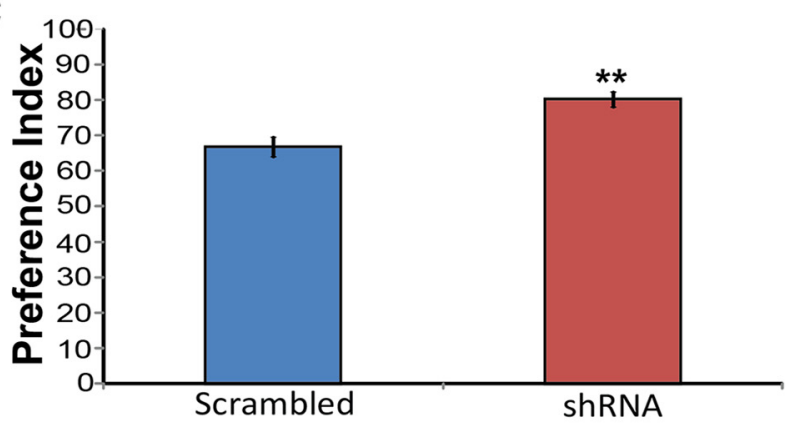

E

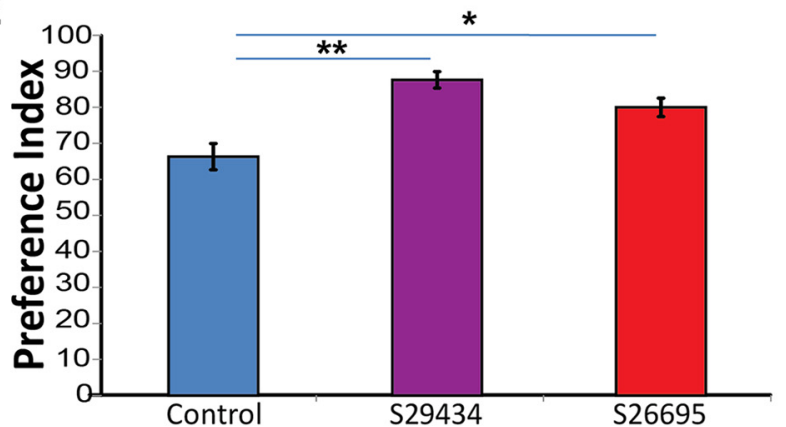

G

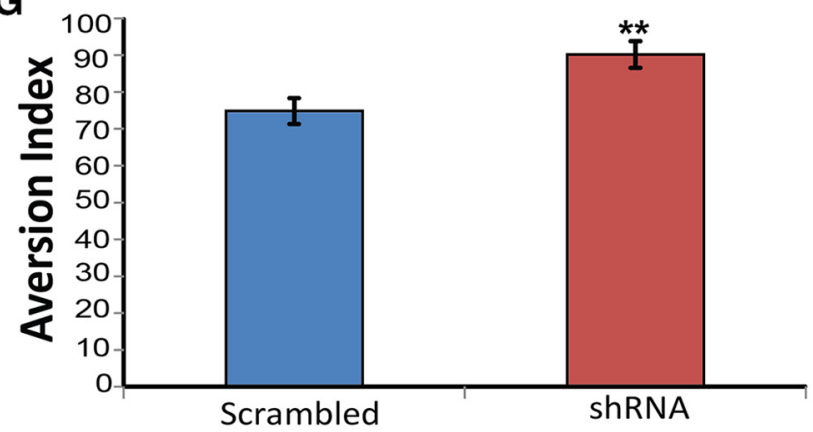

I

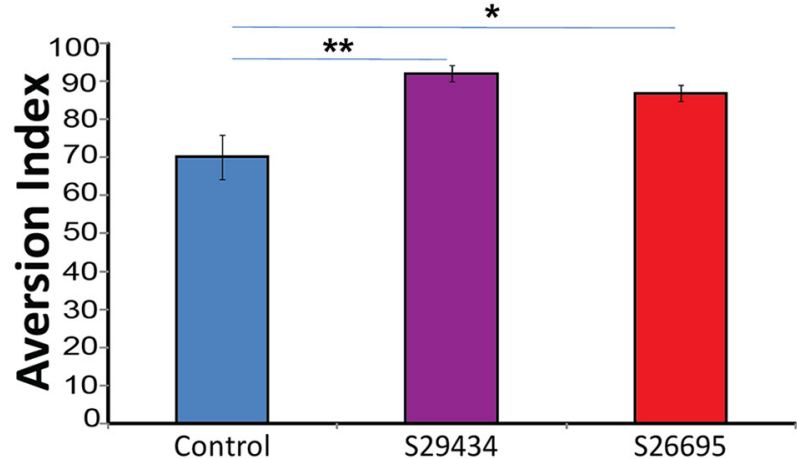

Figure 7. Decreasing either QR2 expression or activity enhances positive and negative novel taste learning. $A$, Structure of lentiviral vectors injected into the IC. Top, Vector containing QR2 shRNA injected to the test group. Bottom, Scrambled vector injected to the control group. $\boldsymbol{B}$, Experimental design to determine the effect of reducing QR2 mRNA expression on novel taste memory. $\boldsymbol{C}$, Animals injected with QR2 shRNA show significantly enhanced learning of the novel taste compared with control (scrambled, $n=12$; shRNA, $n=10$ ). $\boldsymbol{D}$, Experimental design to determine the effect of inhibiting QR2 activity on taste memory. Animals were injected with QR2 inhibitors $\$ 29434$ or $\$ 26695$ (8 mg/kg, i.p.) or saline (control). E, Animals injected with either of the QR2 inhibitors display significantly enhanced learning of the novel taste compared with control $(n=8) . \boldsymbol{F}$, Experimental design to determine the effect of reducing QR2 mRNA expression on negative taste memory (CTA). $G$, Animals injected with QR2 shRNA show significantly enhanced learning of the negative association of the novel taste compared with control (scrambled, $n=7 ;$ shRNA, $n=8)$. $\boldsymbol{H}$, Experimental design to determine the effect of inhibiting QR2 activity on negative taste memory (CTA). Animals were injected with QR2 inhibitors $\$ 29434$ or $\$ 26695$ (8 mg/kg, i.p.) or saline (control). I, Animals injected with either of the QR2 inhibitors display significantly enhanced learning of the negative association of the novel taste compared with control $(n=8)$. 
one-way $\operatorname{ANOVA} F_{(2,21)}=14, n=8, p \ll$ 0.001, Fisher's LSD post hoc test (vehicle/ S29434) $p \ll 0.001$, Fisher's LSD post hoc test (vehicle/S26695) $p=0.003$.

\section{Decreasing QR2 mRNA expression or inhibiting QR2 activity enhances negative taste learning}

To further demonstrate that reducing QR2 mRNA expression or QR2 activity enhances taste learning, we used a negative form of the taste learning paradigm. We administered the same lentiviral vector expressing QR2 shRNA used above (Figs. 6, 7A) stereotaxically into the IC. We then evaluated the performance of the animals injected with the QR2 shRNA vector compared with those injected with a scrambled-sequence vector in a CTA learning paradigm (Fig. $7 F$ ). These results demonstrate that the a priori reduction of QR2 mRNA expression in the IC not only enhances positive forms of taste learning, as seen above (Fig. 7C), but also enhances negative taste learning (Fig. $7 G$; unpaired Student's $t$ test, $t_{12.969}=-3.12$, scr: $n=7$, shRNA: $n=8, p=0.009)$. In addition, animals that were injected with either one of the synthetic inhibitors, S29434 or S26695, when subjected to the CTA learning paradigm (Fig. $7 H$ ), also demonstrated enhanced performance [Fig. 7I; one-way ANOVA $F_{(2,21)}=9.1, n=8, p=0.0011$, Fisher's LSD post hoc test (vehicle/S29434) $p=0.001$, Fisher's LSD post hoc test (vehicle/S26695) $p=0.0051]$. These results confirm that inhibiting QR2 activity enhances both positive and negative corticaldependent taste learning, as does the reduction of QR2 mRNA expression in the IC.

\section{Decreasing QR2 mRNA expression affects learning but not retrieval}

We wanted to ensure that decreasing QR2 mRNA expression levels in the cortex does not enhance newly encoded memories at the expense of previously encoded ones nor cause any encountered stimuli to be treated as novel ones, even if they are familiar. To evaluate this, we performed a retrieval paradigm (Fig. 8A). The animals underwent a CTA learning paradigm. We then administered the same lentiviral vector expressing QR2 shRNA or control used above stereotaxically (Figs. 6, 7A). We hypothesized that, if reducing QR2 expression using a lentiviral vector expressing QR2 shRNA would cause the animals to treat all stimuli as novel, then they would not show aversion toward the novel taste. The animals were then tested to evaluate the aversive memory previously encoded. There was no difference between the groups, indicating that decreasing QR2 mRNA in the IC does not have a negative effect on the ability to recall previously encoded memories (Fig. $8 B$; unpaired Student's $t$ test, $t_{14}=0.5$, scr: $n=7$, shRNA: $n=8, p=0.651$ ).

We then confirmed that these animals had enhanced taste learning abilities by subjecting them to a second CTA paradigm using $\mathrm{NaCl}$ as a novel taste learning paradigm (Fig. $8 A$ ). The animals injected with the lentiviral vector expressing QR2 shRNA performed significantly better than those injected with the scrambled virus (Fig. $8 C$; unpaired Student's $t$ test, $t_{8.862}=-2.3$, scr: $n=7$, shRNA: $n=8, p=0.046)$. These results further confirm that decreasing QR2 mRNA expression in the IC enhances taste learning without affecting previously encoded taste memories or taste recognition.

\section{QR2 mRNA is overexpressed in AD patients}

Human QR2 is very similar to rodent QR2 on the molecular and functional levels (Payton et al., 2010). It has been demonstrated that patients with $\mathrm{AD}$ overexpress $\mathrm{QR} 2$ protein in the hippocampus (Hashimoto and Nakai, 2011). We measured cortical QR2 mRNA from AD patients and healthy aged matched controls. AD patients express chronically higher levels of QR2 mRNA in the frontal cortex (Brodmann area 8; Fig. 9; unpaired Student's $t$ test, $t_{29.041}=2.2$, healthy controls: $n=11$, AD patients: $n=27, p=$ $0.034)$. We had no information on the medication regimen of the patients, which may affect correlative measurements. However, one would assume that, if some of the subjects were treated with acetylcholineesterase inhibitors, then the QR2 levels would be decreased rather than increased.

\section{Discussion}

After differential screening of genes with expression that is modulated in the IC of rats that underwent the taste learning paradigm, we demonstrated that the novelty component in novel taste learning leads to and is dependent upon decreased QR2 mRNA expression in the IC. This decrease in QR2 mRNA expression is downstream from mAChR activation. Furthermore, we have established that the inhibition of QR2 activity or the reduction of QR2 mRNA expression in the IC enhances novel taste learning. This corresponds to previous work (Benoit et al., 2010) 


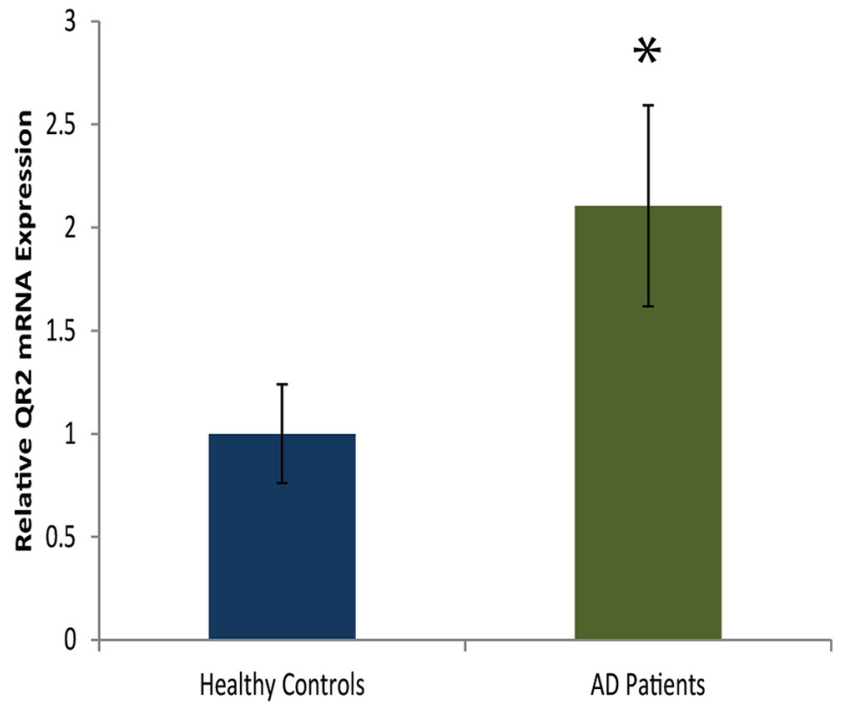

Figure 9. $A D$ patients overexpress $Q R 2 m R N A$ in the frontal cortex. $Q R 2$ mRNA expression is significantly higher in $A D$ patients compared with healthy controls (healthy, $n=11$; $A D$ patients, $n=27$ ).

in which scopolamine-induced animal models for age-related cognitive deficiencies had a partial recovery of ability to perform in hippocampal-related tasks after their exposure to a QR2 inhibitor. Interestingly, in the current work, we identify a direct link among mAChR activation, QR2 expression, and corticaldependent cognitive enhancement.

Our results have several significant ramifications (Lee and Silva, 2009). First, QR2 is a constraint on cortical-dependent memory consolidation, which is removed endogenously by novel information that is mediated via an $\mathrm{mAChR}$ activation. Moreover, we draw a correlative and causal link between a value of given sensory information (i.e., novelty), activation of $\mathrm{mAChR}$, and reduced expression of QR2 in the relevant cortical area.

The physiological function of QR2 in neurons and its mechanism of action are currently unknown, mainly because the endogenous substrates of QR2 remain unknown or in question. Based on the literature, there are few conceivable molecular or cellular theoretical possibilities to explain the effect of QR2 on memory. The first possibility is that QR2 reduces oxidative stress similarly to QR1 (Dinkova-Kostova and Talalay, 2010; Sachdeva et al., 2014). QR2 may affect dopamine by triggering the double reduction of the dopamine quinone, as shown in a study using the model of the developing chick retina (Sampaio et al., 2014). Indeed, QR2 has been shown to protect against neurotoxic $o$-quinones, free radicals formed during catecholamine metabolism. As a result, oxidative stress, which is involved in the etiology of age-related cognitive impairment and $\mathrm{AD}$, is reduced (Payton et al., 2010).

Another possibility is that QR2 interacts with the proteasome machinery. For example, both QR1 and QR2 protect the tumor suppressor p53 against degradation by regulating the ubiquitinindependent proteasomal 20S pathway and QR1 has been shown to accumulate in brains of some $\mathrm{AD}$ patients due to defective regulation of E3 ligase STUB1/CHIP (Tsvetkov et al., 2011). Interestingly, both proteasome-mediated protein degradation and protein synthesis are necessary for memory consolidation in a brain-region-specific manner (Sonenberg and Dever, 2003; Elkobi et al., 2008; Barki-Harrington et al., 2009; Belelovsky et al., 2009; Stern et al., 2013; Chinnakkaruppan et al., 2014; Ounallah-
Saad et al., 2014; Rosenberg et al., 2014). In a recent study done in SH-SY5Y neuroblastoma cells, the synthesis of Arc/Arg3.1, an immediate early gene necessary for synaptic plasticity, was shown to be increased after $\mathrm{mAChR}$ stimulation, whereas proteasomal degradation limited the amount and duration of Arc/Arg3.1 expression. Furthermore, mimicking rapid eye movement sleep epochs in conjunction with application of the mAChR agonist carbachol, a combination associated with long-term synaptic plasticity and memory, generates persistent, maximal ERKdependent Arc/Arg3.1 expression (Soulé et al., 2012). Therefore, this interplay of the cholinergic system and proteasomal machinery may be mediated at least in part via QR2.

From a cellular perspective, it is possible that QR2 affects intrinsic properties of neurons and/or synaptic plasticity. However, QR2 KO mice do not show any difference in LTP or LTD in the hippocampus compared with WT littermates (Benoit et al., 2010). One must be cautious in ruling out this possibility because this mouse model involves complete prenatal knock-out of QR2, which may lead to developmental compensatory processes to overcome this loss of function mutation. In addition, other protocols to induce LTP/LTD should be tested. Furthermore, it is possible that QR2 levels affect neuronal intrinsic properties to exert its effect on memory processes (Cohen-Matsliah et al., 2008, 2009, 2010). A massive effort should be taken to prove or refute the theoretical hypotheses for the downstream effect of QR2 on brain function and learning. However, our findings draw for the first time a clear link upstream to QR2 expression, that is, the relationship among novel sensory information, QR2 expression in the relevant cortical structure, the muscarinic acetylcholine system, and memory strength.

From a clinical perspective, our work opens new possibilities for the treatment of neurodegenerative diseases. The very few known treatments for memory enhancement in neurodegenerative diseases include ACh esterase inhibitors (Hansen et al., 2008; Gauthier and Scheltens, 2009), which have the potential to interfere with other nonrelated physiological processes (Gauthier and Scheltens, 2009; Witte et al., 2014). The identification of QR2 as a clear downstream target that can explain the enhanced memory effect of ACh esterase inhibitors positions it as a prime new target for memory enhancement. Interestingly, $\mathrm{AD}$ patients overexpress QR2 protein and mRNA (Hashimoto and Nakai, 2011 and Fig. 9). There are numerous factors implicated as being involved in $\mathrm{AD}$, such as TAU pathology, $\mathrm{A} \beta_{42}$ levels, plaque load, age, and the number of APOE $\varepsilon 4$ alleles (Murray et al., 2015). Further studies are needed to delineate the relationship between QR2 and these factors.

It has also been shown recently that resveratrol, a known QR2 inhibitor (Ferry et al., 2010), leads to improved memory performance (Witte et al., 2014). Our results, in addition to shedding light on molecular mechanisms underlying endogenous neuromodulatory effects on learning and exogenous pharmacological effects on memory, provide a promising new downstream target for treating cognitive dysfunction in different pathologies ranging from mild cognitive impairment to AD.

\section{Notes}

Supplemental material for this article is available at http://neurosenblum. haifa.ac.il/images/stories/supp_info/cta_microarray.xls. Provided are data on screening mRNA expression in the insular cortex after CTA learning This material has not been peer reviewed.

\section{References}

Acquas E, Wilson C, Fibiger HC (1996) Conditioned and unconditioned stimuli increase frontal cortical and hippocampal acetylcholine release: 
effects of novelty, habituation, and fear. J Neurosci 16:3089-3096. Medline

Aloisi AM, Casamenti F, Scali C, Pepeu G, Carli G (1997) Effects of novelty, pain and stress on hippocampal extracellular acetylcholine levels in male rats. Brain Res 748:219-226. CrossRef Medline

Baratti CM, Huygens P, Mino J, Merlo A, Gardella J (1979) Memory facilitation with posttrial injection of oxotremorine and physostigmine in mice. Psychopharmacology (Berl) 64:85-88. CrossRef Medline

Barki-Harrington L, Belelovsky K, Doron G, Rosenblum K (2009) Molecular mechanisms of taste learning in the insular cortex and amygdala. In: Conditioned taste aversion: behavioral and neural processes (Reilly S, Schachtman TR, eds), pp 341-363. Oxford: OUP.

Belelovsky K, Kaphzan H, Elkobi A, Rosenblum K (2009) Biphasic activation of the mTOR pathway in the gustatory cortex is correlated with and necessary for taste learning. J Neurosci 29:7424-7431. CrossRef Medline

Benoit CE, Bastianetto S, Brouillette J, Tse Y, Boutin JA, Delagrange P, Wong $\mathrm{T}$, Sarret P, Quirion R (2010) Loss of quinone reductase 2 function selectively facilitates learning behaviors. J Neurosci 30:12690-12700. CrossRef Medline

Berger BD (1972) Conditioning of food aversions by injections of psychoactive drugs. J Comp Physiol Psychol 81:21-26. CrossRef Medline

Bermúdez-Rattoni F (2004) Molecular mechanisms of taste-recognition memory. Nat Rev Neurosci 5:209-217. Medline

Bures J, Bermúdez-Rattoni F, Yamamoto Y (1998) Conditioned taste aversion: memory of a special kind. Oxford: OUP.

Chinnakkaruppan A, Wintzer ME, McHugh TJ, Rosenblum K (2014) Differential contribution of hippocampal subfields to components of associative taste learning. J Neurosci 34:11007-11015. CrossRef Medline

Cohen-Matsliah SI, Seroussi Y, Rosenblum K, Barkai E (2008) Persistent ERK activation maintains learning-induced long-lasting modulation of synaptic connectivity. Learn Mem 15:756-761. CrossRef Medline

Cohen-Matsliah SI, Rosenblum K, Barkai E (2009) Olfactory-learning abilities are correlated with the rate by which intrinsic neuronal excitability is modulated in the piriform cortex. Eur J Neurosci 30:1339-1348. CrossRef Medline

Cohen-Matsliah SI, Motanis H, Rosenblum K, Barkai E (2010) A novel role for protein synthesis in long-term neuronal plasticity: maintaining reduced postburst afterhyperpolarization. J Neurosci 30:4338-4342. CrossRef Medline

Davis KL, Mohs RC (1982) Enhancement of memory processes in Alzheimer's disease with multiple-dose intravenous physostigmine. Am J Psychiatry 139:1421-1424. CrossRef Medline

Dinkova-Kostova AT, Talalay P (2010) NAD(P)H:quinone acceptor oxidoreductase 1 (NQO1), a multifunctional antioxidant enzyme and exceptionally versatile cytoprotector. Arch Biochem Biophys 501:116-123. CrossRef Medline

Elkobi A, Ehrlich I, Belelovsky K, Barki-Harrington L, Rosenblum K (2008) ERK-dependent PSD-95 induction in the gustatory cortex is necessary for taste learning, but not retrieval. Nat Neurosci 11:1149-1151. CrossRef Medline

Ferry G, Hecht S, Berger S, Moulharat N, Coge F, Guillaumet G, Leclerc V, Yous S, Delagrange P, Boutin JA (2010) Old and new inhibitors of quinone reductase 2. Chem Biol Interact 186:103-109. CrossRef Medline

Gal-Ben-Ari S, Rosenblum K (2011) Molecular mechanisms underlying memory consolidation of taste information in the cortex. Front Behav Neurosci 5:87. Medline

Gauthier S, Scheltens P (2009) Can we do better in developing new drugs for Alzheimer's disease? Alzheimers Dement 5:489-491. CrossRef Medline

Giovannini MG, Rakovska A, Benton RS, Pazzagli M, Bianchi L, Pepeu G (2001) Effects of novelty and habituation on acetylcholine, GABA, and glutamate release from the frontal cortex and hippocampus of freely moving rats. Neuroscience 106:43-53. CrossRef Medline

Graves PR, Kwiek JJ, Fadden P, Ray R, Hardeman K, Coley AM, Foley M, Haystead TA (2002) Discovery of novel targets of quinoline drugs in the human purine binding proteome. Mol Pharmacol 62:1364-1372. CrossRef Medline

Gutiérrez R, Téllez LA, Bermúdez-Rattoni F (2003) Blockade of cortical muscarinic but not NMDA receptors prevents a novel taste from becoming familiar. Eur J Neurosci 17:1556-1562. CrossRef Medline

Guzman-Karlsson MC, Meadows JP, Gavin CF, Hablitz JJ, Sweatt JD (2014) Transcriptional and epigenetic regulation of Hebbian and non-Hebbian plasticity. Neuropharmacology 80:3-17. CrossRef Medline
Hansen RA, Gartlehner G, Webb AP, Morgan LC, Moore CG, Jonas DE (2008) Efficacy and safety of donepezil, galantamine, and rivastigmine for the treatment of Alzheimer's disease: a systematic review and metaanalysis. Clin Interv Aging 3:211-225. Medline

Harada S, Fujii C, Hayashi A, Ohkoshi N (2001) An association between idiopathic Parkinson's disease and polymorphisms of phase II detoxification enzymes: glutathione S-transferase M1 and quinone oxidoreductase 1 and 2. Biochem Biophys Res Commun 288:887-892. CrossRef Medline

Harada S, Tachikawa H, Kawanishi Y (2003) A possible association between an insertion/deletion polymorphism of the NQO2 gene and schizophrenia. Psychiatr Genet 13:205-209. CrossRef Medline

Hashimoto T, Nakai M (2011) Increased hippocampal quinone reductase 2 in Alzheimer's disease. Neurosci Lett 502:10-12. CrossRef Medline

Inberg S, Elkobi A, Edri E, Rosenblum K (2013) Taste familiarity is inversely correlated with Arc/Arg3.1 hemispheric lateralization. J Neurosci 33: 11734-11743. CrossRef Medline

Iskander K, Paquet M, Brayton C, Jaiswal AK (2004) Deficiency of NRH:quinone oxidoreductase 2 increases susceptibility to 7,12-dimethylbenz(a)anthracene and benzo(a)pyrene-induced skin carcinogenesis. Cancer Res 64:5925-5928. CrossRef Medline

Johansen JP, Cain CK, Ostroff LE, LeDoux JE (2011) Molecular mechanisms of fear learning and memory. Cell 147:509-524. CrossRef Medline

Kandel ER (2001) The molecular biology of memory storage: a dialogue between genes and synapses. Science 294:1030-1038. CrossRef Medline

Kandel ER, Schwartz JH, Jessell TM (2000) Principles of Neural Science. New York: McGraw-Hill, Health Professions Division.

Kolb B, Tees RC (1990) The cerebral cortex of the rat. Cambridge, MA: MIT.

Kwiek JJ, Haystead TA, Rudolph J (2004) Kinetic mechanism of quinone oxidoreductase 2 and its inhibition by the antimalarial quinolines. Biochemistry 43:4538-4547. CrossRef Medline

Lee YS, Silva AJ (2009) The molecular and cellular biology of enhanced cognition. Nat Rev Neurosci 10:126-140. CrossRef Medline

Lois C, Hong EJ, Pease S, Brown EJ, Baltimore D (2002) Germline transmission and tissue-specific expression of transgenes delivered by lentiviral vectors. Science 295:868-872. Medline

Merhav M, Rosenblum K (2008) Facilitation of taste memory acquisition by experiencing previous novel taste is protein-synthesis dependent. Learn Mem 15:501-507. CrossRef Medline

Mesulam MM, Geula C, Morán MA (1987) Anatomy of cholinesterase inhibition in Alzheimer's disease: effect of physostigmine and tetrahydroaminoacridine on plaques and tangles. Ann Neurol 22:683-691. CrossRef Medline

Miranda MI, Ramírez-Lugo L, Bermúdez-Rattoni F (2000) Cortical cholinergic activity is related to the novelty of the stimulus. Brain Res 882: 230-235. CrossRef Medline

Murray ME, Lowe VJ, Graff-Radford NR, Liesinger AM, Cannon A, Przybelski SA, Rawal B, Parisi JE, Petersen RC, Kantarci K, Ross OA, Duara R, Knopman DS, Jack CR Jr, Dickson DW (2015) Clinicopathologic and 11C-Pittsburgh compound B implications of Thal amyloid phase across the Alzheimer's disease spectrum. Brain 138:1370-1381. Medline

Naor C, Dudai Y (1996) Transient impairment of cholinergic function in the rat insular cortex disrupts the encoding of taste in conditioned taste aversion. Behav Brain Res 79:61-67. CrossRef Medline

Ounallah-Saad H, Sharma V, Edry E, Rosenblum K (2014) Genetic or pharmacological reduction of PERK enhances cortical-dependent taste learning. J Neurosci 34:14624-14632. CrossRef Medline

Payton A, Miyajima F, Ollier W, Rabbitt P, Pickles A, Weiss V, Pendleton N, Horan M (2010) Investigation of a functional quinine oxidoreductase (NQO2) polymorphism and cognitive decline. Neurobiol Aging 31:351352. CrossRef Medline

Pegan SD, Sturdy M, Ferry G, Delagrange P, Boutin JA, Mesecar AD (2011) $\mathrm{X}$-ray structural studies of quinone reductase 2 nanomolar range inhibitors. Protein Sci 20:1182-1195. CrossRef Medline

Postma NS, Mommers EC, Eling WM, Zuidema J (1996) Oxidative stress in malaria; implications for prevention and therapy. Pharm World Sci 18: 121-129. CrossRef Medline

Ranganath C, Rainer G (2003) Neural mechanisms for detecting and remembering novel events. Nat Rev Neurosci 4:193-202. CrossRef Medline

Rosenberg T, Gal-Ben-Ari S, Dieterich DC, Kreutz MR, Ziv NE, Gundelfinger ED, Rosenblum K (2014) The roles of protein expression in synaptic plasticity and memory consolidation. Front Mol Neurosci 7:86. Medline Rosenblum K, Meiri N, Dudai Y (1993) Taste memory: the role of protein 
synthesis in gustatory cortex. Behav Neural Biol 59:49-56. CrossRef Medline

Ryan TA, Reuter H, Wendland B, Schweizer FE, Tsien RW, Smith SJ (1993) The kinetics of synaptic vesicle recycling measured at single presynaptic boutons. Neuron 11:713-724. CrossRef Medline

Sachdeva MM, Cano M, Handa JT (2014) Nrf2 signaling is impaired in the aging RPE given an oxidative insult. Exp Eye Res 119:111-114. CrossRef Medline

Sampaio Lde FS, Mesquita FP, de Sousa PR, Silva JL, Alves CN (2014) The melatonin analog 5-MCA-NAT increases endogenous dopamine levels by binding NRH:quinone reductase enzyme in the developing chick retina. Int J Dev Neurosci 38:119-126. CrossRef Medline

Sano Y, Shobe JL, Zhou M, Huang S, Shuman T, Cai DJ, Golshani P, Kamata M, Silva AJ (2014) CREB regulates memory allocation in the insular cortex. Curr Biol 24:2833-2837. CrossRef Medline

Singh N, Parle M (2003) Sildenafil improves acquisition and retention of memory in mice. Indian J Physiol Pharmacol 47:318-324. Medline

Sonenberg N, Dever TE (2003) Eukaryotic translation initiation factors and regulators. Curr Opin Struct Biol 13:56-63. CrossRef Medline

Soulé J, Alme M, Myrum C, Schubert M, Kanhema T, Bramham CR (2012) Balancing Arc synthesis, mRNA decay, and proteasomal degradation: maximal protein expression triggered by rapid eye movement sleep-like bursts of muscarinic cholinergic receptor stimulation. J Biol Chem 287: 22354-22366. CrossRef Medline

Stern E, Chinnakkaruppan A, David O, Sonenberg N, Rosenblum K (2013) Blocking the eIF2alpha kinase (PKR) enhances positive and negative forms of cortex-dependent taste memory. J Neurosci 33:2517-2525. CrossRef Medline

Tsvetkov P, Adamovich Y, Elliott E, Shaul Y (2011) E3 ligase STUB1/CHIP regulates $\mathrm{NAD}(\mathrm{P}) \mathrm{H}$ :quinone oxidoreductase $1(\mathrm{NQO1})$ accumulation in aged brain, a process impaired in certain Alzheimer disease patients. J Biol Chem 286:8839-8845. CrossRef Medline

Wang W, Jaiswal AK (2004) Sp3 repression of polymorphic human NRH: quinone oxidoreductase 2 gene promoter. Free Radic Biol Med 37:12311243. CrossRef Medline

Warburton DM (1969) Behavioral effects of central and peripheral changes in acetylcholine systems. J Comp Physiol Psychol 68:56-64. CrossRef Medline

Witte AV, Kerti L, Margulies DS, Flöel A (2014) Effects of resveratrol on memory performance, hippocampal functional connectivity, and glucose metabolism in healthy older adults. J Neurosci 34:7862-7870. CrossRef Medline 